\title{
Ability of 3 tanniferous forage legumes to modify quality of milk and Gruyère-type cheese
}

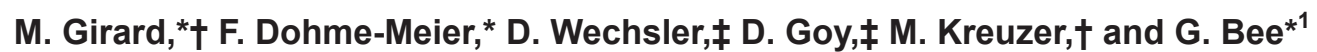 \\ *Institute for Livestock Sciences ILS, Agroscope, Tioleyre 4, 1725 Posieux, Switzerland \\ †Institute of Agricultural Science, ETH Zurich, Universitaetstrasse 2, 8092 Zurich, Switzerland \\ łInstitute for Food Sciences IFS, Agroscope, Schwarzenburgstrasse 161, 3003 Bern, Switzerland
}

\begin{abstract}
Condensed tannins (CT) may affect ruminal biohydrogenation of dietary polyunsaturated fatty acids. A feeding experiment was conducted with 24 Holstein cows to evaluate whether diets containing $\mathrm{CT}$ from different forage legumes can increase polyunsaturated fatty acids, especially n-3 fatty acid content in milk and cheese, without affecting negatively their physicochemical and sensorial properties. Cows were assigned to 4 treatment groups $(\mathrm{n}=6)$ for $52 \mathrm{~d}$, divided into 2 periods: a control period $(\mathrm{CoP})$ and an experimental period (ExP). During the CoP, cows received a basal diet composed of hay, corn silage, ExtruLin (Trinova Handel \& Marketing AG, Wangen, Switzerland), concentrate, and alfalfa $(\mathrm{AF})$ in a ratio of 45:25:5:7:18. In the ExP, in 3 of the 4 groups AF was replaced by either sainfoin (SF; $19 \%$ CT in dry matter) or 1 of 2 cultivars of birdsfoot trefoil [Polom (BP), 3\% CT; Bull (BB), 5\% CT]. At the end of each period, milk was collected on 3 consecutive days and analyzed for milk gross composition and fatty acid profile and was processed to Gruyère-type cheese. A trained panel assessed the sensory quality of raw milk and cheese using discriminative and descriptive tests. This experimental design consisting of AF in both the $\mathrm{CoP}$ and ExP allowed us to quantify effects due to lactation stage and experimental diets. In both the $\mathrm{CoP}$ and ExP, dry matter intake and milk yield did not differ among treatment groups. From the $\mathrm{CoP}$ to the ExP, milk urea content was reduced by $23 \%$ with SF, remained unchanged with $\mathrm{BP}$, and tended to increase with $\mathrm{AF}$ and $\mathrm{BB}$. The odor of the raw $\mathrm{BB}$ milk was judged to be different from AF milk. With SF, switching from the CoP to the ExP resulted in a $17 \%$ increase of the 18:3n-3 proportion in milk and cheese lipids. In
\end{abstract}

Received June 12, 2015.

Accepted October 1, 2015.

${ }^{1}$ Corresponding author: giuseppe.bee@agroscope.admin.ch
$\mathrm{BP}$ cheese, the increase was $3 \%$, whereas it tended to decrease in BB cheese. Additionally, the 20:5n-3 and 22:5n-3 proportions tended to increase in SF cheese from the CoP to the ExP. Compared with the AF cheeses, cheeses from cows fed CT-containing legumes were judged harder and tended to be less adhesive to the palate. In addition, $\mathrm{SF}$ and $\mathrm{BP}$ cheeses had less rind. In conclusion, feeding SF compared with $\mathrm{BB}$ and $\mathrm{BP}$ increased the content of $18: 3 \mathrm{n}-3$ in the milk and the cheese without a negative effect on flavor of the cheese. Despite a similar CT content, the 2 birdsfoot trefoil cultivars had opposite effects on milk urea and 18:3n3 deposition, suggesting that, besides the content, the chemical structure may have had an important effect on the CT efficacy.

Key words: condensed tannins, milk, cheese, quality

\section{INTRODUCTION}

The fatty acid profile of milk and dairy products is considered to be not ideal with respect to human health and being one reason for the decrease in milk consumption in some industrialized countries (Cavadini et al., 2000; Haug et al., 2007). The main concern is the high proportion of some SFA, known to increase blood levels of total cholesterol and low-density lipoproteins in humans who consume large amounts of these types of fatty acids (Williams, 2000; Mensink et al., 2003; Shingfield et al., 2008). The rather low proportion of unsaturated fatty acids, in particular PUFA, in milk fat occurs despite the high PUFA content of grass-based dairy diets. For instance, the study of Dohme-Meier and Bee (2012) showed that less than $25 \%$ of the PUFA ingested is secreted in the milk. The main cause for the low PUFA transfer rate is the biohydrogenation of dietary PUFA and MUFA by rumen microbes, mostly bacteria belonging to Butyrivibrio genus. In the rumen, the isomerase from Butyrivibrio fibrisolvens converts 18:2n-6 (linoleic acid) to 18:2 cis-9,trans-11 (rumenic acid) and then hydrogenates 18:2 cis-9,trans-11 to 
18:1 trans-11 (vaccenic acid). Starting with a different step, 18:3n-3 ( $\alpha$-linolenic acid) is isomerized to 18:3 cis-9,trans-11, cis-15, then converted to 18:2 trans11,cis-15, but then also hydrogenated to 18:1 trans-11 (Kepler et al., 1966). In the last step of the fatty acid biohydrogenation process in the rumen, 18:1 trans-11 is hydrogenated by Butyrivibrio proteoclasticum to 18:0 (stearic acid) (Wallace et al., 2006). The disappearance of $18: 3 \mathrm{n}-3$ and $18: 2 \mathrm{n}-6$ in the rumen was, on average, 93 and 85\%, respectively (Doreau and Ferlay, 1993). From a dietetic point of view, $18: 3 n-3$ and 18:2n-6 are important in human nutrition because the human body cannot synthesize them and both are precursors of nutritionally important long-chain fatty acids of the n-3 and n- 6 families. They are widely studied for their positive effects on human health, especially 20:5n-3 (eicosapentaenoic acid), 22:5n-3 (docosapentaenoic acid), and 22:6n-3 (docosahexaenoic acid) (Deckelbaum and Torrejon, 2012).

Nutritional strategies in dairy cows that reduce ruminal biohydrogenation of dietary PUFA and MUFA could be the key to improve milk quality with respect to human requirements. Several studies based on the use of condensed tannins (CT) showed a potential for $\mathrm{CT}$ to modulate in vitro and in vivo biohydrogenation in the rumen by changing rumen microbial population, sometimes affecting both growth and protease activity of the bacteria (Jones et al., 1994; Khiaosa-Ard et al., 2009; Vasta et al., 2010). Recently, Buccioni et al. (2015) observed in vivo that feeding quebracho tannins (1.6\% of DMI) to ewes increased the relative abundance of Butyrivibrio fibrisolvens and decreased that of $\mathrm{Bu}$ tyrivibrio proteoclasticum compared with a tannin-free diet. Likewise, Vasta et al. (2009b) hypothesized that CT might indirectly regulate $\Delta^{9}$-desaturase expression, an enzyme involved in the conversion of 18:0 to 18:1 cis-9 and 18:1 trans-11 to $18: 2$ cis-9,trans-11 in the muscle and in the mammary gland via a modulation of absorbed fatty acids and protein levels. The results of these 2 previous experiments are consistent with the beneficial effect of CT on fat quality of ruminant products (Turner et al., 2005), but some failed to show an effect (Aprianita et al., 2014). Many factors can influence the bioactivity of $\mathrm{CT}$, such as the proportion of $\mathrm{CT}$ in the diet, the chemical structure of $\mathrm{CT}$, the length of the period during which CT are fed, and the type of diet to which CT were added. For instance, Vasta et al. (2009a) found that CT included in concentrate were more efficient against biohydrogenation than when offered together with green herbage.

Preserving PUFA and MUFA, making dietary products more susceptible to oxidation, could also have negative consequences from a consumer's point of view. It is, therefore, important to ensure that the final product (milk or cheese) still has a pleasant taste and is free of off-flavors. Thus, CT feeding might create more intense flavors and even off-flavors, which would be more perceptible in products in which fat is concentrated. For instance, during storage, buttermilk from milk rich in unsaturated fatty acids was found to be more likely to oxidize than buttermilk from milk richer in SFA (Kristensen et al., 2004). Furthermore, oxidized flavors, such as fishy flavor, were positively correlated with increased proportions of $18: 2 \mathrm{n}-6$ and $18: 3 \mathrm{n}-3$ in the milk fat after $8 \mathrm{~d}$ of storage (Timmons et al., 2001). Finally, when the products are kept for a longer period, such as ripened cheese, the incidence of oxidation may be especially high. Consequently, the use of diets containing plants rich in bioactive compounds (CT included) have to be evaluated carefully as to whether they influence the organoleptic quality of dairy products (Martin et al., 2005).

The hypotheses tested in the present study were (1) that it is possible to elevate the proportions of $n-6$ and, especially, n-3 PUFA in milk and cheese lipids, (2) but that this adversely affects its odor and flavor, and (3) that the occurrence and levels of these effects depend on genotype (species, cultivar) of the CT-providing plants. For this purpose, 3 legume genotypes with known different CT content and likely different CT properties were grown and they were added to a PUFA n-3-enriched diet for dairy cows to promote differences in ruminal biohydrogenation.

\section{MATERIALS AND METHODS}

\section{Experimental Legumes}

Four legume forages were cultivated in Posieux, Switzerland (latitude: $46^{\circ} 46^{\prime} \mathrm{N}$, longitude: $07^{\circ} 06^{\prime} \mathrm{E}$; altitude: $650 \mathrm{~m}$ ) in 2012. These were a non-CT control legume, alfalfa (Medicago sativa cultivar Sanditi; AF), sainfoin (Onobrychis viciifolia cultivar Perly; SF), and 2 birdsfoots trefoil cultivars [Lotus corniculatus cultivars Bull (BB) and Polom (BP)]. From the second harvest, wilted forages were dried in a rotary barrel (type 5.0, Kunz, Langnau, Switzerland). The drying process was a succession of short heating and cooling periods repeated 3 times. The heating and cooling source delivered temperatures of 700 and $82^{\circ} \mathrm{C}$, respectively. This process lasted for a total of $240 \mathrm{~s}$. Finally, dried forages were ground $(<3 \mathrm{~mm})$ and pressed into 2 -cm cylindrical pellets.

\section{Animals, Diet Composition, and Sampling}

The experiment was conducted in accordance with the Swiss guidelines for animal welfare and approved by 
the Swiss cantonal veterinary office (approval number: 2012_48_FR).

The feeding experiment, which lasted $52 \mathrm{~d}$, was conducted with 24 lactating Holstein cows. At the beginning of the study, they were allocated in groups of 6 to 1 of the 4 experimental groups balancing milk yield, contents of milk fat and protein, and DIM (initial means \pm SD: $30.7 \pm 5.6 \mathrm{~kg} / \mathrm{d}, 4.21 \pm 0.52$ and $3.01 \pm$ $0.29 \%$, and $78.3 \pm 22.3 \mathrm{~d}$, respectively). The experiment was subdivided into 2 periods, a control period (CoP; from d 1 to 24) and an experimental period (ExP; from d 28 to 52), with a progressive adaptation to the feed from d 25 to 27. Each period consisted of a 21-d adaptation period followed by a 3 -d sample collection period $(\mathrm{CoP}=\mathrm{d} 22$ through $24 ; \mathrm{ExP}=\mathrm{d} 50$ through 52, respectively). In the $\mathrm{CoP}$, all cows were offered the same diet, which consisted, on a DM basis, of a mixture of grass hay (86:10:4 of grass, legumes, and other species, respectively), corn silage, and extruded flaxseed (ExtruLin, Trinova Handel \& Marketing AG, Wangen, Switzerland) in a ratio of 60:33:7, as well as $\mathrm{AF}$ pellets and a mixture of 2 concentrate types in amounts meeting their individual predicted nutrient requirements (Agroscope, 2014). ExtruLin was chosen to generate diets with high fat and 18:3n-3 contents. In detail, an energy concentrate consisting of barley, corn, wheat, and beet molasses (32:32:32:4) and a protein concentrate containing soybean cake, corn gluten, potato protein, and beet molasses (60:25:10:5) were used. In addition, the cows received daily $60 \mathrm{~g}$ of $\mathrm{NaCl}$ and 50 $\mathrm{g}$ of a mineral mixture containing (per $\mathrm{kg}$ ) $104 \mathrm{~g}$ of $\mathrm{Ca}$, $65 \mathrm{~g}$ of P, $25 \mathrm{~g}$ of $\mathrm{Mg}, 66 \mathrm{~g}$ of $\mathrm{Na}, 1.3 \mathrm{~g}$ of $\mathrm{Zn}, 6.6 \mathrm{mg}$ of Se, $20 \mathrm{mg}$ of I, $3.3 \mathrm{mg}$ of Co, $160 \mathrm{mg}$ of $\mathrm{Cu}, 67 \mathrm{mg}$ of biotin, 200,000 IU of vitamin A, 16,000 IU of vitamin $\mathrm{D}_{3}$, and 1,300 IU of vitamin $\mathrm{E}$. The daily target amount of $\mathrm{AF}$ pellets was $20 \%$ of DMI. In ExP, 1 experimental group continued to receive the AF pellets, whereas for the other 3 groups the AF pellets were replaced by either SF, BB, or BP pellets.

During the experiment, cows were kept in individual tiestalls with ad libitum access to water. Feed was offered in 2 equal meals always directly after milking (0530 $\mathrm{h}$ and $1600 \mathrm{~h}$ ) in the following order: first, pellets and concentrate were offered together in a bucket at 0615 and $1645 \mathrm{~h}$, then $30 \mathrm{~min}$ later the mixture of hay, corn silage, and ExtruLin was offered on the floor. This allowed us to determine separately the refusals of the pellets and concentrate as well as the mixture of hay, corn silage, and ExtruLin. Feed consumption and milk yield were recorded daily. In the first $3 \mathrm{wk}$ of $\mathrm{CoP}$ and $\mathrm{ExP}$, hay, corn silage, ExtruLin, and pellets were individually collected once a week, whereas, on the collection days, the same components as well as the concentrate were collected daily and stored at $-20^{\circ} \mathrm{C}$. Additionally, in both experimental periods, milk samples were collected every morning and evening. Depending on the milk yield of the morning and evening milking, aliquots were prepared and pooled. From these samples, a portion was stored at $-20^{\circ} \mathrm{C}$ for later determination of milk urea content and fatty acid profile. The remaining part was stored for later determination of gross composition in tubes containing Broad-Spectrum Microtabs II (Gerber Instruments AG, Effretikon, Switzerland) at $5^{\circ} \mathrm{C}$.

\section{Experimental Cheese Manufacturing}

From the milk obtained on the sampling days in CoP and ExP, Swiss Gruyère-type cheese, a major cheese produced in Switzerland, per experimental group was prepared daily using morning and evening milk. This resulted in a total of 24 cheeses in the experiment. This procedure was chosen, as this cheese has to be prepared from unpasteurized fresh milk and the daily milk amount of the 6 cows per group was necessary for the production of 1 cheese of the typical size of this brand. The Gruyère-type cheeses were produced as previously described by Casey et al. (2004). Briefly, $100 \mathrm{~mL}$ of fresh $(\mathrm{pH} 4.9)$ and old $(\mathrm{pH} 4.25)$ starter culture were added to $120 \mathrm{~L}$ of fresh milk. This milk was preripened for $30 \mathrm{~min}$ at 31 to $32^{\circ} \mathrm{C}$ then coagulated for $40 \mathrm{~min}$ at $32^{\circ} \mathrm{C}$. After cutting and stirring at $32^{\circ} \mathrm{C}$ for $20 \mathrm{~min}$, temperature was increased to $56^{\circ} \mathrm{C}$ for $40 \mathrm{~min}$. Then, the curd-whey mixture was stirred for 20 min at $56^{\circ} \mathrm{C}$ before the curds were filtered into molds. After brining, final maturation of the Gruyère-type cheeses was accomplished in a cellar at 14 to $15^{\circ} \mathrm{C}(90$ to $96 \%$ relative humidity) for $240 \mathrm{~d}$. From the aged cheeses, 24 samples were taken for later analysis of fatty acid profile and chemical composition and stored at $-20^{\circ} \mathrm{C}$.

\section{Laboratory Analyses}

Feed Analysis. For the chemical analysis, samples of hay, ExtruLin, and pellets from the first $3 \mathrm{wk}$ of $\mathrm{CoP}$ and ExP and the samples taken during collection days, resulting in 4 pooled samples per component, were used. The concentrate samples from each collection sample period were pooled, resulting in 2 pooled samples per concentrate. Prior to analysis, corn silage was dried for $24 \mathrm{~h}$ at $60^{\circ} \mathrm{C}$. The $\mathrm{DM}$ content of all feed samples collected was determined after drying at $105^{\circ} \mathrm{C}$ for $3 \mathrm{~h}$. Before freeze-drying, samples of corn silages were pooled as previously described for hay, ExtruLin, and pellets. Afterward, pooled samples of hay and corn silage were lyophilized (Christ Delta 1-24 LSC, Osterode, Germany). The lyophilized hay and corn silage, as well as ExtruLin, concentrate, and experimental pellets, were ground to pass a 1-mm screen 
(Brabender mill, Brabender, Duisburg, Germany). In these samples, $\mathrm{DM}\left(105^{\circ} \mathrm{C}\right.$ for $\left.3 \mathrm{~h}\right)$ and ash $\left(550^{\circ} \mathrm{C}\right.$ for $4 \mathrm{~h}$ ) were determined. Standard protocols (AOAC International, 1995; procedure no. 973.18) were used to analyze NDF and ADF content. For NDF determination, heat-stable amylase and sodium sulfite were used. Both NDF and ADF levels were expressed without residual ash. The total $\mathrm{N}$ content was quantified using the Dumas method (AOAC International, 2000). The CP content was calculated as $6.25 \times \mathrm{N}$. The fatty acid profile was measured in lyophilized samples as described by Ampuero Kragten et al. (2014). Briefly, lipids were transmethylated in acidic conditions for 3 $\mathrm{h}$ at $70^{\circ} \mathrm{C}$ with $5 \%$ methanolic $\mathrm{HCl}$. The methyl esters formed were neutralized with a solution of potassium carbonate and purified on a silica gel. Finally, FAME were analyzed by GC (6850 Agilent Technologies AG, Basel, Switzerland) equipped with a flame ionization detector and nonadecanoic acid-methylester (19:0) was used as internal standard. Total fat was determined as total fatty acids $\div 0.9565$, where 0.9565 is the average conversion factor of fatty acids to triglycerides. The soluble, protein-bound, fiber-bound, and total CT content of the experimental pellets was determined by using the $\mathrm{HCl}$-Butanol method as described by Terrill et al. (1992). The CT extracted and purified from each plant were used for calibration. Total polyphenols were quantified as described by Salminen and Karonen (2011) using gallic acid (G7384, Sigma-Aldrich Chemie GmbH, Buchs, Switzerland) as standard and expressed as grams of gallic acid equivalent per kilogram of DM.

Milk and Cheese Analysis. The contents of protein, fat, lactose, and casein of the preserved milk were analyzed with a Milkoscan FT (CombiFoss FT, Foss, Gerber Instruments AG, Effretikon, Switzerland) by infrared spectrometry. The milk urea was determined by measuring the differential $\mathrm{pH}$ ( $\mathrm{pH}$-analyzer, Eurochem, Ardea, Italy) before and after hydrolysis with urease (ISO, 2004). Aliquots of milk from the sampling days were defrosted and pooled per cow within $\mathrm{CoP}$ and ExP into 2 samples for the fatty acid profile analysis as previously described (Ampuero Kragten et al., 2014). Briefly, milk fat was extracted according to standard method (ISO, 2001) by centrifugation for $30 \mathrm{~min}$ at $8,500 \times g$ at $4^{\circ} \mathrm{C}$. The supernatant layer cream was removed and a small volume of skim milk was added before being filtered at $60^{\circ} \mathrm{C}$. The resulting filtrate was dissolved in a hexane solution containing an internal standard of nonanoic acid (9:0, Fluka Art. Nr. 76370, Sigma-Aldrich Chemie GmbH, Buchs, Switzerland) and glycerides were transesterified into FAME using a methanolic solution of potassium hydroxide (ISO, 2002). After centrifugation, FAME were quantified by GC (6890 Agilent Technologies AG) equipped with a capillary column (CP-SIL 88, 100 m, i.d. $\times 0.25$ $\mathrm{mm}$, film thickness $0.20 \mu \mathrm{m}$, P.H. Stehelin \& Cie AG, Basel, Switzerland) and coupled with a flame ionization detector. Cheese lipids were extracted by mixing $10 \mathrm{~g}$ of cheese with the same quantity of dehydrated sodium sulfate and by boiling this mixture into a pentane solution at 90 to $100^{\circ} \mathrm{C}$ for $4 \mathrm{~h}$. After evaporating the pentane, the residue was dissolved in $250 \mathrm{~mL}$ of heptane before a final filtration and evaporation step (ISO, 2001). Except for this, the analysis of the fatty acid profile of the cheese fat was accomplished equally to that described for milk fat. The DM content of the cheese samples was determined gravimetrically by drying for $4 \mathrm{~h}$ at $102^{\circ} \mathrm{C}$ after mixing of the cheese with sand (1:1). The fat content of the cheese was measured by dissolving $3 \mathrm{~g}$ (on the DM basis) of cheese with hydrochloric acid and fat was extracted with petroleum ether. Moisture on a free-fat basis and fat in the DM were then estimated. Sodium chloride content was measured indirectly by argentometric titration (ISO, 2006). Volatile carboxylic acids were quantified by steam distillation in sulfuric acid followed by neutralization with a solution of sodium hydroxide (ISO, 2008). The following standards were used: methanoic acid (1:0, Merck Nr. 264, Merck SA, Zug, Switzerland), acetic acid (2:0, Merck Nr. 63, Merck SA), propionic acid (3:0, Fluka Nr. 81910, Sigma-Aldrich Chemie GmbH), butyric acid (4:0, Fluka Nr. 19210, Sigma-Aldrich Chemie GmbH), and caproic acid (6:0, Fluka Nr. 21530, Sigma-Aldrich Chemie $\mathrm{GmbH}$ ). The distillate was esterified with ethanol and the volatile phase was analyzed by GC (HP 5890 Series II, Agilent Technologies AG). Total lactic acid was calculated as the sum of D-lactate and L-lactate, which were quantified enzymatically using an auto-analyzer (Hitachi 902, Roche Diagnostics AG, Rotkreuz, Switzerland). Contents of free AA in cheese were determined as previously described (Bütikofer and Ardö, 1999).

\section{Sensory Analysis of Milk and Cheese}

Sensory evaluation of milk and cheese was performed according to reference methods (O'Mahony, 1992) for the discriminative tests and to standard protocols (ISO, 2003) for the descriptive tests. Twelve panelists were asked to compare the odor of the raw milk used to prepare the cheeses. For hygienic reasons, the trained panel was just allowed to assess this by smelling and not by tasting. The R-index discriminative test was performed (O'Mahony, 1992). Each day, during the 2 sampling periods, panelists had to compare milk from each group (AF, $\mathrm{SF}, \mathrm{BB}$, and $\mathrm{BP}$ ) to a reference sample from the AF group. They were asked to answer the 
question, "Does this milk smell different to that of the reference?" To answer, they could select from 4 given answers: "Yes, I am sure," "Yes, but I am not sure," "No, I am not sure," or "No, I am sure."

After 8 mo of ripening, the cheeses prepared in the $\mathrm{CoP}$ and ExP were rated by the same 12 panelists. Because all cows allocated to the 4 experimental groups were offered the same diet in the CoP, the R-index discriminative test was applied to prove or disprove the similarity regarding flavor and structure of the cheeses from each group ( $\mathrm{AF}, \mathrm{SF}, \mathrm{BB}$, and $\mathrm{BP}$ ) produced in the CoP. In addition, for the sensory test of the samples of cheese from the $\mathrm{AF}, \mathrm{SF}, \mathrm{BB}$, and $\mathrm{BT}$ groups obtained in the ExP, a line scale ranging from 0 (low intensity/ thin) to 10 (high intensity/thick) was applied during 3 sessions. To determine differences in sensorial attributes between cheeses prepared in the $\mathrm{CoP}$ and $\mathrm{ExP}$, in the same session panelists rated a sample of cheese from the $\mathrm{AF}$ group manufactured in the $\mathrm{CoP}$ in addition to the cheeses from the $\mathrm{AF}, \mathrm{SF}, \mathrm{BB}$, and $\mathrm{BT}$ groups obtained in the ExP. The following attributes to describe structure of Gruyère cheese were selected: hardness, sandy texture, thickness of the rind, adhesiveness on the palate. Flavor was described by milky, animal, fruity, aromatic, sweet, salty, umami, sour, and sharp. Panelists were trained as described by Goy et al. (2011). Assessments of each panelist were recorded on a touch screen using the Fizz software (Biosystème, Couternon, France).

\section{Calculations and Statistical Analysis}

Dietary $\mathrm{NE}_{\mathrm{L}}$, absorbable protein at the duodenum content, and ECM were calculated according to Thanner et al. (2014). Because total butyric acid in the cheese can originate both from lipolysis and fermentation, the butyric acid from fermentation was calculated as

$$
\text { 4:0 from fermentation }=\text { total 4:0 }-(3 \times \text { total 6:0 }) \text {, }
$$

where total caproic acid (6:0) originates only from lipolysis.

Data were analyzed by ANOVA with the MIXED procedure of SAS (version 9.2; SAS Institute Inc., Cary, $\mathrm{NC})$. Within treatment, the experimental period (CoP vs. ExP) was used as a fixed effect in the model. Moreover, within experimental period $(\mathrm{CoP}$ and $\mathrm{ExP})$ an ANOVA with experimental treatments (AF, BB, SF, and BP) as fixed effect was performed. Test results from the $\mathrm{CoP}$ are not reported in the tables, but are described in the text where necessary. For multiple comparisons among means, the PDIFF statement of the MIXED procedure was used. Effects were considered significant at $P<0.05$ and a tendency at $0.05<$ $P<0.10$. The R-index score for sensory discrimination of milk and cheese samples in the CoP were calculated according to O'Mahony (1992) and effects were considered as significant at $P<0.05$. Nonparametric statistics on linear grading of the cheese samples in the ExP were performed with a robust rank test based on an ANOVA-type test statistic of the nparLD package for LD.F2 design using the $\mathrm{R}$ software (version 3.1.2; Brunner et al., 2002; Noguchi et al., 2012). The same test was used for pairwise comparisons between $\mathrm{AF}$ in the $\mathrm{CoP}$ and $\mathrm{AF}, \mathrm{BB}, \mathrm{SF}$, and $\mathrm{BP}$ in the ExP. Effects were considered significant at $P<0.05$ and a tendency at $0.05<P<0.10$.

\section{RESULTS}

\section{Feed Composition, Intake, Milk Yield, and Gross Composition}

Hay, corn silage, and ExtruLin had nutrient contents as expected, and a clear difference was noted between the 2 types of concentrate (Table 1). Among the pellets, those prepared from SF had the lowest CP content and a polyphenol content which was 2 to 3 fold greater than the $\mathrm{AF}, \mathrm{BB}$, and $\mathrm{BP}$ pellets. All pellets had a lower $\mathrm{NE}_{\mathrm{L}}$ content as the hay and the corn silage. The $\mathrm{CT}$ in $\mathrm{SF}$ and $\mathrm{BB}$ pellets were mainly composed of soluble CT (54 to $60 \%$ ), and less so of protein- (33 to $35 \%$ ) and fiber-bound CT (7 to 11\%). By contrast, the protein-bound fraction represented 48 versus $42 \%$ for the soluble $\mathrm{CT}$ in the BP pellets. The SF pellets had a much higher CT content than BB and BP pellets (19.1 vs. 4.8 and $3.0 \%$ in DM, respectively). The fatty acid composition of all the ingredients was mainly polyunsaturated, with over $60 \%$ of PUFA and up to $26 \%$ of SFA, except for the mineral mix. The corn silage and the 2 concentrates had a high 18:2n-6 content and a low 18:3n-3 content whereas the hay, the ExtruLin, and the pellets had a low 18:2n-6 content and a high 18:3n-3 content.

The average DMI with the hay-corn silage-ExtruLin mixture, the concentrates, and the pellets did not differ either between treatments or between experimental periods (Table 2). Accordingly, intakes of $\mathrm{CP}, \mathrm{ADF}$, $\mathrm{NDF}, \mathrm{NE}_{\mathrm{L}}$, and total fatty acids were similar in the $\mathrm{CoP}$ and ExP for the 4 experimental groups. Due to the differences in the $\mathrm{CT}$ content between $\mathrm{SF}, \mathrm{BB}$, and BP pellets, $\mathrm{CT}$ intake was greatest $(P<0.01)$ in the $\mathrm{SF}$ group compared with the BB and the BP group and represented 3.0, 0.9, and 0.5\% of total DMI. Compared with the CoP, 18:3n-3 intake was greater $(P=0.05)$ in the ExP for the $\mathrm{SF}$ and $\mathrm{BB}$ groups and tended to be 
Table 1. Analyzed chemical composition (\% of DM unless otherwise stated) of the ingredients of the diets $( \pm \mathrm{SD})$

\begin{tabular}{|c|c|c|c|c|c|c|c|c|c|c|}
\hline \multirow[b]{2}{*}{ tem } & \multicolumn{3}{|c|}{ Mixture } & \multicolumn{3}{|c|}{ Concentrate } & \multicolumn{4}{|c|}{ Pellets ${ }^{1}$} \\
\hline & $\begin{array}{c}\text { Hay } \\
\mathrm{n}=4\end{array}$ & $\begin{array}{l}\text { Corn silage } \\
\mathrm{n}=4\end{array}$ & $\begin{array}{l}\text { ExtruLin }^{2} \\
\mathrm{n}=4\end{array}$ & $\begin{array}{l}\text { Energy } \\
\mathrm{n}=2\end{array}$ & $\begin{array}{l}\text { Protein } \\
\mathrm{n}=2\end{array}$ & $\begin{array}{l}\text { Mineral mix } \\
\quad \mathrm{n}=2\end{array}$ & $\begin{array}{c}\mathrm{AF} \\
\mathrm{n}=4\end{array}$ & $\begin{array}{c}\mathrm{SF} \\
\mathrm{n}=2\end{array}$ & $\begin{array}{c}\mathrm{BB} \\
\mathrm{n}=2\end{array}$ & $\begin{array}{c}\mathrm{BP} \\
\mathrm{n}=2\end{array}$ \\
\hline $\begin{array}{l}\mathrm{DM} \text { (\% of original substance) } \\
\text { Analyzed composition }\end{array}$ & $90.4 \pm 1.3$ & $35.3 \pm 0.5$ & $94.1 \pm 0.2$ & $86.9 \pm 0.6$ & $89.0 \pm 1.0$ & $94.5 \pm 0.3$ & $92.0 \pm 0.3$ & $90.0 \pm 1.2$ & $89.3 \pm 0.4$ & $90.0 \pm 0.2$ \\
\hline $\mathrm{OM}$ & $91.3 \pm 0.8$ & $96.7 \pm 0.2$ & $95.7 \pm 0.1$ & $95.5 \pm 0.3$ & $95.0 \pm 0.4$ & $48.0 \pm 0.1$ & $88.0 \pm 0.4$ & $89.5 \pm 0.1$ & $88.4 \pm 0.1$ & $88.1 \pm 0.1$ \\
\hline $\mathrm{CP}$ & $12.9 \pm 1.0$ & $7.5 \pm 0.2$ & $19.9 \pm 0.2$ & $11.6 \pm 0.3$ & $52.5 \pm 2.5$ & $4.1 \pm 0.1$ & $17.6 \pm 0.7$ & $15.4 \pm 0.5$ & $21.5 \pm 0.2$ & $21.0 \pm 0.4$ \\
\hline $\mathrm{ADF}$ & $27.1 \pm 1.3$ & $23.8 \pm 1.1$ & $18.5 \pm 2.0$ & $5.1 \pm 1.0$ & $17.6 \pm 1.5$ & $7.1 \pm 0.3$ & $36.2 \pm 1.0$ & $32.5 \pm 0.6$ & $31.6 \pm 0.9$ & $31.0 \pm 0.2$ \\
\hline NDF & $48.8 \pm 1.7$ & $51.4 \pm 6.0$ & $47.0 \pm 5.6$ & $14.3 \pm 0.6$ & $30.5 \pm 3.6$ & $14.8 \pm 0.3$ & $44.4 \pm 0.6$ & $33.2 \pm 3.2$ & $37.6 \pm 1.2$ & $34.5 \pm 4.2$ \\
\hline Total & & & & & & & & $19.09 \pm 0.90$ & $4.85 \pm 0.27$ & $3.04 \pm$ \\
\hline Soluble & & & & & & & & $11.46 \pm 1.73$ & $2.63 \pm 0.08$ & $1.28 \pm 0.12$ \\
\hline Protein-bound & & & & & & & & $6.34 \pm 1.88$ & $1.71 \pm 0.24$ & $1.45 \pm 0.28$ \\
\hline Fiber-bound & & & & & & & & $1.29 \pm 0.24$ & $0.51 \pm 0.06$ & $0.31 \pm 0.03$ \\
\hline $\begin{array}{l}\text { Total polyphenols }{ }^{4} \\
\text { Calculated contents }\end{array}$ & & & & & & & $7.70 \pm 0.55$ & $22.4 \pm 0.83$ & $11.3 \pm 0.58$ & $10.7 \pm 0.34$ \\
\hline $\mathrm{NE}_{\mathrm{L}}(\mathrm{MJ} / \mathrm{kg}$ of DM) & $6.19 \pm 0.09$ & $6.58 \pm 0.17$ & $9.64 \pm 0.12$ & 7.98 & 8.48 & 3.26 & $4.76 \pm 0.17$ & $5.19 \pm 0.02$ & $5.16 \pm 0.01$ & $5.12 \pm 0.10$ \\
\hline $\operatorname{ADPE}(\mathrm{g} / \mathrm{kg}$ of $\mathrm{DM})$ & $94.9 \pm 2.65$ & $16.8 \pm 0.46$ & $101.8 \pm 0.82$ & 105.1 & 333.6 & 31.1 & $95.3 \pm 1.36$ & $94.3 \pm 0.88$ & $105.7 \pm 2.01$ & $107.4 \pm 0.60$ \\
\hline $\begin{array}{l}\text { ADPN }(\mathrm{g} / \mathrm{kg} \text { of } \mathrm{DM}) \\
\text { atty acids ( } \% \text { of total fatty } \\
\text { acids) }\end{array}$ & $81.8 \pm 6.77$ & $44.6 \pm 1.28$ & $136.1 \pm 1.52$ & 82.4 & 424.8 & 24.5 & $114.0 \pm 4.52$ & $99.0 \pm 3.10$ & $136.6 \pm 2.85$ & $140.1 \pm 1.60$ \\
\hline $16: 0$ & $15.5 \pm 0.06$ & $12.9 \pm 0.37$ & 6.0 & $15.8 \pm 0.15$ & $12.7 \pm 0.62$ & $23.2 \pm$ & $16.7 \pm 0.57$ & $15.7 \pm 0.01$ & $15.5 \pm 0.24$ & $14.9 \pm 0.01$ \\
\hline 18:0 & $1.4 \pm 0.11$ & $1.7 \pm 0.13$ & $3.0 \pm 0.05$ & $1.5 \pm 0.07$ & $3.1 \pm 0.74$ & $13.4 \pm 0.03$ & $2.7 \pm 0.14$ & $2.2 \pm 0.01$ & $1.6 \pm 0.13$ & $1.4 \pm 0.06$ \\
\hline $18: 2 \mathrm{n}-6$ & $14.9 \pm 0.43$ & $52.2 \pm 1.92$ & $16.8 \pm 0.14$ & $56.1 \pm 2.40$ & $47.3 \pm 0.22$ & $13.0 \pm 0.89$ & $17.4 \pm 0.42$ & $16.3 \pm 0.25$ & $17.4 \pm 0.12$ & $17.2 \pm 0.18$ \\
\hline $18: 3 n-3$ & $49.8 \pm 0.70$ & $5.6 \pm 0.34$ & $52.1 \pm 0.03$ & $3.2 \pm 0.05$ & $5.4 \pm 0.48$ & $1.3 \pm 0.15$ & $42.5 \pm 0.72$ & $45.7 \pm 0.35$ & $46.2 \pm 0.01$ & $47.1 \pm 0.79$ \\
\hline SFA & $22.0 \pm 0.63$ & $16.9 \pm 0.72$ & $9.9 \pm 0.07$ & $18.5 \pm 0.34$ & $17.7 \pm 1.52$ & $42.9 \pm 0.04$ & $26.3 \pm 1.28$ & $25.0 \pm 0.77$ & $22.6 \pm 0.06$ & $21.6 \pm 0.14$ \\
\hline MUFA & $5.3 \pm 0.47$ & $22.0 \pm 1.32$ & $18.0 \pm 0.04$ & $19.6 \pm 2.12$ & $27.1 \pm 1.74$ & $41.5 \pm 1.00$ & $5.4 \pm 1.13$ & $6.1 \pm 0.34$ & $5.9 \pm 0.39$ & $5.6 \pm 0.11$ \\
\hline PUFA & $72.7 \pm 0.77$ & $61.0 \pm 1.91$ & $72.2 \pm 0.03$ & $61.9 \pm 2.46$ & $55.2 \pm 0.22$ & $15.5 \pm 1.04$ & $68.3 \pm 0.85$ & $68.9 \pm 0.85$ & $71.5 \pm 0.33$ & $72.8 \pm 0.25$ \\
\hline
\end{tabular}

${ }^{1} \mathrm{AF}=$ alfalfa; $\mathrm{SF}=$ sainfoin; $\mathrm{BP}=$ birdsfoot trefoil Polom; $\mathrm{BB}=$ birdsfoot trefoil Bull.

${ }^{2}$ ExtruLin (Trinova Handel \& Marketing AG, Wangen, Switzerland).

${ }^{3}$ Total fat was calculated as total fatty acids $\div 0.9565$

${ }^{4}$ Total polyphenols are expressed as grams of gallic acid equivalent per kilogram of DM.

${ }^{5}$ Calculated contents of net energy and absorbable protein as described by Thanner et al. (2014). APD = absorbable protein at the duodenum when rumen fermentable energy (APDE) or nitrogen $(\mathrm{APDN})$ is limiting microbial protein synthesis in the rumen. 
Table 2. Feed and nutrient intake of cows fed during the control period $(\mathrm{CoP})$ and when fed the different legumes in the experimental period (ExP)

\begin{tabular}{|c|c|c|c|c|c|c|c|c|c|c|c|c|c|c|c|c|c|c|}
\hline \multirow[b]{2}{*}{ Item } & \multicolumn{4}{|c|}{ Alfalfa } & \multicolumn{4}{|c|}{ Sainfoin } & \multicolumn{4}{|c|}{ Birdsfoot trefoil Bull } & \multicolumn{4}{|c|}{ Birdsfoot trefoil Polom } & \multicolumn{2}{|c|}{ Treatment effect } \\
\hline & $\begin{array}{c}\mathrm{CoP} \\
\mathrm{n}=6\end{array}$ & $\begin{array}{c}\mathrm{ExP} \\
\mathrm{n}=6\end{array}$ & SEM & $P$-value & $\begin{array}{c}\mathrm{CoP} \\
\mathrm{n}=6\end{array}$ & $\begin{array}{c}\mathrm{ExP} \\
\mathrm{n}=6\end{array}$ & SEM & $P$-value & $\begin{array}{c}\mathrm{CoP} \\
\mathrm{n}=6\end{array}$ & $\begin{array}{c}\mathrm{ExP} \\
\mathrm{n}=6\end{array}$ & SEM & $P$-value & $\begin{array}{c}\mathrm{CoP} \\
\mathrm{n}=6\end{array}$ & $\begin{array}{c}\mathrm{ExP} \\
\mathrm{n}=6\end{array}$ & SEM & $P$-value & SEM & $P$-value \\
\hline \multicolumn{19}{|l|}{$\begin{array}{l}\text { Feed intake (kg of } \\
\mathrm{DM} / \text { cow per day) }\end{array}$} \\
\hline Mixture & 16.4 & 16.6 & 0.64 & 0.81 & 16.4 & 17.2 & 0.63 & 0.39 & 17.0 & 17.8 & 0.92 & 0.51 & 16.4 & 16.9 & 1.02 & 0.75 & 0.87 & 0.73 \\
\hline Concentrate & 1.4 & 1.5 & 0.45 & 0.85 & 1.7 & 1.8 & 0.57 & 0.89 & 1.1 & 1.0 & 0.45 & 0.95 & 2.1 & 2.2 & 0.70 & 0.87 & 0.58 & 0.50 \\
\hline Pellets & 4.3 & 3.8 & 0.29 & 0.25 & 4.3 & 3.6 & 0.36 & 0.23 & 4.3 & 4.2 & 0.24 & 0.94 & 4.4 & 3.9 & 0.25 & 0.18 & 0.37 & 0.61 \\
\hline Total & 22.0 & 21.9 & 0.89 & 0.91 & 22.4 & 22.7 & 0.79 & 0.81 & 22.3 & 23.1 & 1.43 & 0.69 & 22.9 & 23.0 & 1.47 & 0.96 & 1.20 & 0.86 \\
\hline \multicolumn{19}{|l|}{$\begin{array}{l}\text { Nutrient intake } \\
\text { (per cow per day) }\end{array}$} \\
\hline $\mathrm{CP}(\mathrm{kg})$ & 3.0 & 3.0 & 0.13 & 0.78 & 3.0 & 3.0 & 0.11 & 0.84 & 3.0 & 3.3 & 0.20 & $\begin{array}{r}<0.01 \\
0.23\end{array}$ & 3.1 & 3.3 & 0.21 & 0.45 & $\begin{array}{r}41.00 \\
0.17\end{array}$ & $\begin{array}{r}<0.01 \\
0.36\end{array}$ \\
\hline $\mathrm{ADF}(\mathrm{kg})$ & 5.9 & 5.7 & 0.17 & 0.33 & 5.9 & 5.6 & 0.18 & 0.29 & 6.0 & 5.9 & 0.31 & 0.82 & 6.0 & 5.6 & 0.25 & 0.31 & 0.23 & 0.73 \\
\hline NDF (kg) & 10.4 & 10.1 & 0.33 & 0.48 & 10.5 & 9.9 & 0.32 & 0.27 & 10.6 & 10.5 & 0.57 & 0.85 & 10.6 & 10.0 & 0.54 & 0.45 & 0.46 & 0.77 \\
\hline $\mathrm{NE}_{\mathrm{L}}(\mathrm{MJ})$ & 138 & 139 & 6.37 & 0.92 & 141 & 146 & 5.90 & 0.56 & 139 & 146 & 9.68 & 0.62 & 144 & 148 & 10.79 & 0.82 & 7.87 & 0.87 \\
\hline \multicolumn{19}{|l|}{$\begin{array}{r}\text { Fatty acid intake } \\
\text { (g/cow per day) }\end{array}$} \\
\hline $14: 0$ & 2.77 & 2.88 & 0.08 & 0.35 & 2.78 & 2.89 & 0.08 & 0.39 & 2.82 & 3.17 & 0.15 & 0.14 & 2.82 & 3.05 & 0.12 & 0.21 & 0.12 & 0.22 \\
\hline $16: 0$ & 104.7 & 106.4 & 4.62 & 0.80 & 106.5 & 110.8 & 4.19 & 0.49 & 105.7 & 115.8 & 7.18 & 0.35 & 109.0 & 115.4 & 7.76 & 0.57 & 6.34 & 0.64 \\
\hline $16: 1$ cis-9 & 1.04 & $5.61^{\mathrm{b}}$ & 0.09 & $<0.01$ & 1.05 & $5.29^{\mathrm{b}}$ & 0.12 & $<0.01$ & 1.05 & $6.71^{\mathrm{a}}$ & 0.22 & $<0.01$ & 1.07 & $6.50^{\mathrm{a}}$ & 0.15 & $<0.01$ & 0.22 & $<0.01$ \\
\hline $18: 0$ & 19.6 & 20.8 & 0.75 & 0.28 & 19.8 & 21.1 & 0.71 & 0.21 & 19.8 & 21.4 & 1.21 & 0.38 & 20.1 & 20.8 & 1.34 & 0.70 & 1.07 & 0.96 \\
\hline $18: 1$ cis-9 & 110.4 & 112.2 & 5.67 & 0.84 & 112.8 & 118.9 & 5.79 & 0.47 & 111.4 & 116.7 & 8.11 & 0.65 & 115.0 & 118.6 & 10.15 & 0.81 & 7.94 & 0.91 \\
\hline $18: 1 \mathrm{cis}-11$ & 5.02 & 5.63 & 0.26 & 0.13 & 5.12 & 6.08 & 0.25 & 0.02 & 5.05 & 6.00 & 0.38 & 0.11 & 5.22 & 6.18 & 0.46 & 0.18 & 0.38 & 0.72 \\
\hline $18: 2 \mathrm{n}-6$ & 240.4 & 236.5 & 13.59 & 0.84 & 246.7 & 249.1 & 13.97 & 0.91 & 241.1 & 247.2 & 19.04 & 0.82 & 253.5 & 259.5 & 23.59 & 0.86 & 19.04 & 0.85 \\
\hline $18: 3 n-3$ & 325.2 & 346.8 & 10.51 & 0.18 & 325.1 & 360.7 & 11.19 & 0.05 & 333.9 & 391.9 & 18.4 & 0.05 & 327.4 & 372.5 & 16.58 & 0.09 & 15.42 & 0.17 \\
\hline $20: 0$ & 3.20 & $3.20^{\mathrm{b}}$ & 0.11 & 0.99 & 3.22 & $4.14^{\mathrm{a}}$ & 0.13 & $<0.01$ & 3.24 & $3.53^{\mathrm{b}}$ & 0.19 & 0.31 & 3.28 & $3.38^{\mathrm{b}}$ & 0.19 & 0.70 & 0.17 & $<0.01$ \\
\hline $20: 1$ & 1.03 & 1.06 & 0.07 & 0.78 & 1.07 & 1.14 & 0.08 & 0.59 & 1.03 & 1.16 & 0.10 & 0.37 & 1.11 & 1.16 & 0.13 & 0.77 & 0.11 & 0.88 \\
\hline $22: 0$ & 3.24 & $3.04^{\mathrm{b}}$ & 0.10 & 0.16 & 3.26 & $3.63^{\mathrm{a}}$ & 0.12 & 0.06 & 3.30 & $3.23^{\mathrm{ab}}$ & 0.17 & 0.80 & 3.30 & $3.06^{\mathrm{b}}$ & 0.15 & 0.30 & 0.14 & 0.01 \\
\hline SFA & 138.2 & 142.3 & 5.77 & 0.63 & 140.3 & 148.5 & 5.19 & 0.29 & 139.8 & 153.7 & 9.17 & 0.31 & 143.3 & 151.8 & 9.73 & 0.55 & 7.97 & 0.71 \\
\hline MUFA & 122.8 & 127.7 & 6.17 & 0.59 & 125.3 & 134.5 & 6.24 & 0.32 & 124.0 & 134.2 & 8.97 & 0.44 & 127.8 & 136.0 & 11.03 & 0.61 & 8.69 & 0.89 \\
\hline PUFA & 566.2 & 583.7 & 23.18 & 0.61 & 572.5 & 610.4 & 21.93 & 0.25 & 575.7 & 639.9 & 36.95 & 0.25 & 581.5 & 632.9 & 39.58 & 0.39 & 32.93 & 0.57 \\
\hline Total & 852.8 & 879.7 & 35.56 & 0.60 & 863.6 & 918.3 & 33.50 & 0.28 & 865.4 & 956.8 & 56.27 & 0.28 & 878.4 & 949.3 & 61.06 & 0.44 & 50.21 & 0.64 \\
\hline
\end{tabular}

() ${ }^{\mathrm{a}-\mathrm{c}}$ Treatment means in the ExP within the same row carrying no common superscript differ significantly at $P<0.05$.

${ }^{1}$ Condensed tannins. 
greater $(P=0.09)$ for the BP group. Furthermore, in the ExP 20:0 and 22:0 intakes were greater $(P<0.05)$ in the SF compared with the other groups and were also greater than in the CoP.

Yields of milk, fat, protein, and lactose did not differ among dietary treatments and, within treatment, between the CoP and $\mathrm{ExP}$ (Table 3); the same is true for fat and lactose contents. In the ExP, but also in the $\mathrm{CoP}$, the milk protein content was greater $(P<0.01)$ in the $\mathrm{BB}$ compared with the $\mathrm{AF}, \mathrm{SF}$, and $\mathrm{BP}$ groups (data not shown for the comparison in the CoP). Between the $\mathrm{CoP}$ and $\mathrm{ExP}$, the $\mathrm{CN}$ content increased in the $\mathrm{AF}, \mathrm{SF}$, and $\mathrm{BT}$ groups, whereas it stayed unchanged in the BB group. However, only in the AF group did this increase tend $(P=0.06)$ to result in an increase in the $\mathrm{CN}$ yield. Both experimental periods and treatments had an effect $(P<0.01)$ on milk urea content. From the CoP to the ExP, milk urea tended $(P<0.08)$ to increase by $8 \%$ in the $\mathrm{AF}$ and $\mathrm{BB}$ group, remained unchanged in the $\mathrm{BP}$, and decreased $(P<0.01)$ by $23 \%$ in the SF group. In the ExP, the lowest $(P<0.01)$ milk urea level was observed in the milk of cows fed SF.

\section{Fatty Acid Profile of Milk and Cheese Lipids}

Milk. Except for small changes in the proportions of some individual fatty acids, the proportions of total SFA, MUFA, PUFA, CLA, n-3, n-6, and short-, medium-, and long-chain fatty acids proportion in the milk remained unchanged from the $\mathrm{CoP}$ to the $\mathrm{ExP}$ and were not affected by the dietary treatment (Table 4). From the CoP to the ExP, the 4:0 proportion increased $(P<$ $0.05)$ with $\mathrm{AF}$ and tended $(P=0.06)$ to increase with SF. The 20:0 proportion tended $(P=0.06)$ to decrease with $\mathrm{AF}$ and 8:0 proportion generally decreased $(P=$ 0.01 to $=0.06)$ by up to $10 \%$ in all dietary treatments. Feeding SF pellets resulted in a tendency $(P=0.08)$ to lower the 18:1 trans-10 and trans-11 levels and BP increased $(P=0.05)$ the proportion of $18: 2$ cis-9,trans-11 of total CLA, respectively. In addition, from the CoP to the ExP, feeding SF resulted in a trend $(P=0.07)$ toward a $17 \%$ increase in the 18:3n-3 level.

Cheese. In comparison to the milk, the fatty acid profile of the cheese was clearly more affected by the period and the treatments (Table 5). However, the comparison between the 4 treatments needs to be considered with caution because the proportions of some of these fatty acids already differed among (the later) treatment groups in the CoP. Feeding the BP diet tended $(P=$ $0.06)$ to increase the proportion of the short-chain fatty acids, mainly by increasing $(P<0.01)$ 8:0 and 10:0 proportion. Conversely, feeding SF in the ExP resulted in a lower $(P<0.01) 10: 0$ proportion. From the CoP to the ExP, the total medium-chain fatty acid levels de-

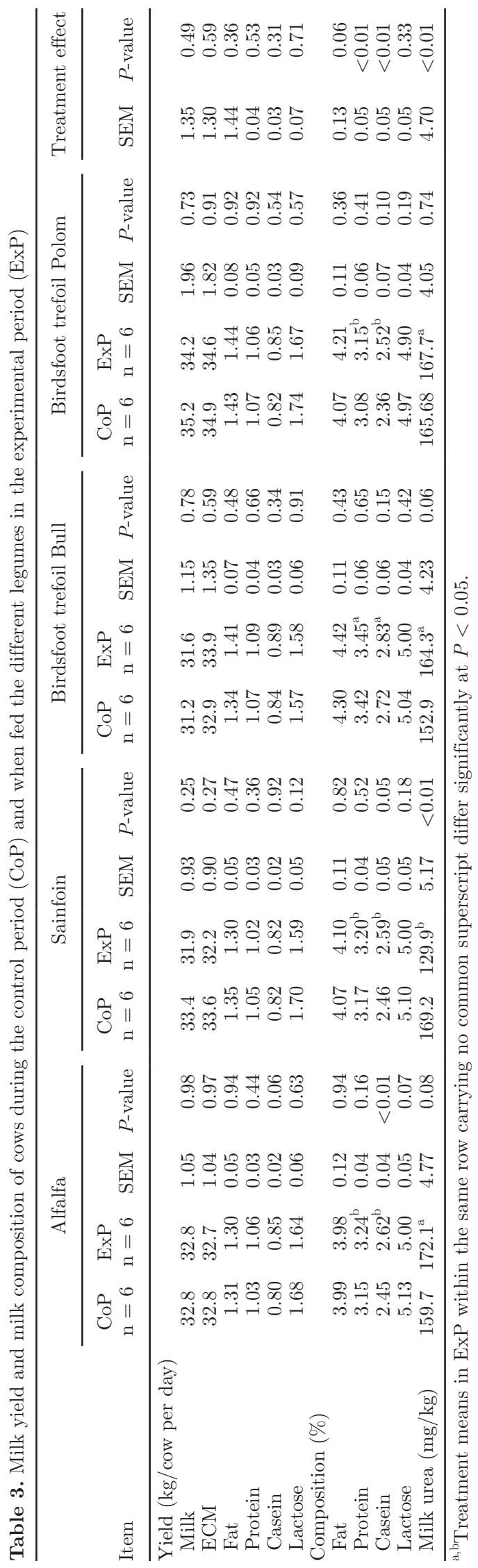


creased $(P<0.05)$ in the BP group, tended $(P=0.07)$ to increase in the AF group, and their levels remained unaffected in the SF and BB groups. Although the level of 12:0 and 14:0 slightly increased $(P<0.01)$ due to BP feeding in the ExP compared with the CoP, the total level of medium-chain fatty acids decreased because of the lower $(P<0.01)$ 16:0 level. By contrast, feeding SF and BB increased $(P<0.05)$ the 16:0 level. Moreover, the 14:0 proportion tended $(P=0.06)$ to be greater in the ExP compared with the CoP for the BB group, whereas for the SF, proportions of 12:0, 14:0, and 15:0 were lower $(P<0.05)$. Feeding the BP pellets resulted in an increase $(P<0.01$ and $P=0.07$, respectively $)$ in the proportion of the long-chain fatty acids and 18:0, whereas their levels were lowered $(P=0.07)$ when SF pellets were fed. Except in the BP group, where no changes were observed, in the $\mathrm{AF}, \mathrm{SF}$, and $\mathrm{BB}$ groups total n-6 fatty acids proportions in the cheeses were lower $(P<0.05)$ in the ExP than in the CoP. In the BB group, this change resulted from a decrease $(P<$ $0.05)$ in 18:2n-6, 20:3 n-6, and 20:4 n-6 proportions. By contrast, feeding SF slightly elevated $(P<0.05)$ the $18: 2 \mathrm{n}-6$ level in the cheese. The lipids in the cheese produced from cows fed the SF pellets had a $9 \%$ greater $(P$ $<0.01)$ n-3 fatty acid proportion, mainly because of a $18 \%$ greater $18: 3 \mathrm{n}-3(P<0.01)$ level, whereas a trend $(P$ $=0.06)$ toward the opposite effect was observed in the $\mathrm{BB}$ group. Furthermore, from the CoP to the ExP, the 20:5n-3 and 22:5n-3 proportions increased $(P<0.10)$ for cheeses from cows fed SF. The CLA proportion in the cheese lipids was not affected by the dietary treatments. The effects of the 2 birdsfoot trefoil cultivars on the fatty acid profile of the cheese differed. From the $\mathrm{CoP}$ to the ExP, although 18:3n-3 tended $(P=$ $0.07)$ to decrease in the BB group, it slightly increased $(P=0.04)$ in the BP group. Feeding BB elevated $(P$ $<0.01)$ the SFA proportion whereas feeding the BP decreased $(P=0.04)$ its level. In the BB group this was compensated by both a lower MUFA and PUFA level $(P=0.06$ and $P<0.05)$, whereas in the BP group only the MUFA level increased $(P<0.05)$.

\section{Chemical Composition of Cheese}

The effects of the treatments on cheese composition were small (Table 6). Between the CoP and the ExP, contents of moisture, moisture on a free-fat basis, and sodium chloride were similar among all the cheeses. Only the fat content tended $(P=0.10)$ to be lower in cheeses from cows fed $\mathrm{AF}$ in the ExP compared with the CoP. Compared with the CoP, cows fed CT-rich plants had less $(P<0.07)$ total lactic acid in the ExP, whereas the content of free AA remained unchanged over periods. Cheeses produced by cows fed AF and
BB tended $(P<0.10)$ to contain more methanoic acid in the ExP compared with the CoP, whereas cheeses produced from cows fed SF and BP tended $(P<0.10)$ to contain more butyric acid, especially due to a greater $(P<0.05)$ contribution of 4:0 from fermentation to total butyric acid.

\section{Sensory Grading of Milk and Cheese}

The odor of the raw milk of each group was assessed and compared with the reference milk (milk from cows fed $\mathrm{AF}$ ). In the CoP, no differences were observed between the odor of the raw milk compared with that of the reference milk (milk from cows fed AF), whereas in the ExP panelists noticed that the milk from cows fed BB was different $(P<0.05)$ from that of cows fed AF (data not shown). No differences in odor intensity were found between the SF and BT compared with the AF groups.

The discrimination test did not reveal differences between the 12 cheeses made in the CoP (data not shown). However, some differences between treatments in terms of texture and flavor were noticed for the 12 cheeses made during the ExP (Table 7). Cheeses from cows fed AF were of similar sensory quality in the CoP and ExP, except for rind thickness which was thinner in the CoP than in the ExP. Furthermore, cheeses produced with milk from cows fed CT-rich legumes were harder $(P<0.05)$ and tended $(P=0.08)$ to be less adhesive to the palate than those from the AF group. Moreover, cheeses from the SF and BP group had less rind $(P<0.05)$ than the ones from cows fed $\mathrm{AF}$ and $\mathrm{BB}$. Cheeses from cows fed SF and BP were less sour $(P<0.05)$ than those from the BB group. The descriptors sandy, milky, animal, fruity, aromatic, sweet, salty, umami, and sharp were judged similarly $(P>0.10)$ among all cheeses.

\section{DISCUSSION}

\section{Effect on Feed Intake, Performance, and Milk Gross Composition}

Some antinutritional effects on feed intake, growth, and milk performances in ruminants have been reported after feeding forages containing CT (Aerts et al., 1999). However, these effects seem to depend on the level of CT ingested, plant species, and animal species consuming the forage and their feeding behavior. For instance, Lotus pedonculatus seems to have more detrimental effects on animal performance than Lotus corniculatus (Aerts et al., 1999). In the experiment by Dschaak et al. (2011), a 3\% (on a DM basis) supplementation of quebracho $\mathrm{CT}$ extract decreased feed intake but had 
Table 5. Fatty acid profile of cheeses (\% of total fatty acids) produced from the milk of cows during the control period (CoP) and when fed the different legumes in the experimental period (ExP)

\begin{tabular}{|c|c|c|c|c|c|c|c|c|c|c|c|c|c|c|c|c|c|c|}
\hline \multirow[b]{2}{*}{ Item } & \multicolumn{4}{|c|}{ Alfalfa } & \multicolumn{4}{|c|}{ Sainfoin } & \multicolumn{4}{|c|}{ Birdsfoot treofoil Bull } & \multicolumn{4}{|c|}{ Birdsfoot trefoil Polom } & \multicolumn{2}{|c|}{$\begin{array}{l}\text { Treatment } \\
\text { effect }\end{array}$} \\
\hline & $\begin{array}{c}\mathrm{CoP} \\
\mathrm{n}=3\end{array}$ & $\begin{array}{c}\mathrm{ExP} \\
\mathrm{n}=3\end{array}$ & SEM & $P$-value & $\begin{array}{c}\mathrm{CoP} \\
\mathrm{n}=3\end{array}$ & $\begin{array}{c}\mathrm{ExP} \\
\mathrm{n}=3\end{array}$ & SEM & $P$-value & $\begin{array}{c}\mathrm{CoP} \\
\mathrm{n}=3\end{array}$ & $\begin{array}{c}\mathrm{ExP} \\
\mathrm{n}=3\end{array}$ & SEM & $P$-value & $\begin{array}{c}\mathrm{CoP} \\
\mathrm{n}=3\end{array}$ & $\begin{array}{c}\mathrm{ExP} \\
\mathrm{n}=3\end{array}$ & SEM & $P$-value & SEM & $P$-value \\
\hline $4: 0$ & 3.79 & $3.72^{\mathrm{y}}$ & 0.09 & 0.63 & 3.94 & $4.05^{x}$ & 0.05 & 0.21 & 3.48 & $3.76^{\mathrm{xy}}$ & 0.14 & 0.25 & 3.89 & $3.90^{\mathrm{xy}}$ & 0.05 & 0.95 & 0.08 & 0.08 \\
\hline $6: 0$ & 2.53 & 2.51 & 0.04 & 0.71 & 2.59 & 2.59 & 0.01 & 0.94 & 2.44 & 2.49 & 0.05 & 0.47 & 2.52 & 2.55 & 0.02 & 0.30 & 0.03 & 0.19 \\
\hline $8: 0$ & 1.55 & 1.53 & 0.02 & 0.47 & 1.52 & 1.51 & 0.01 & 0.35 & 1.69 & 1.61 & 0.08 & 0.53 & 1.51 & 1.56 & 0.01 & $<0.01$ & 0.05 & 0.49 \\
\hline 10:0 & 3.45 & $3.35^{\mathrm{a}}$ & 0.05 & 0.23 & 3.22 & $3.15^{\mathrm{b}}$ & 0.01 & $<0.01$ & 3.50 & $3.40^{\mathrm{a}}$ & 0.04 & 0.10 & 3.28 & $3.41^{\mathrm{a}}$ & 0.01 & $<0.01$ & 0.03 & $<0.01$ \\
\hline $12: 0$ & 3.70 & $3.62^{\mathrm{b}}$ & 0.05 & 0.26 & 3.46 & $3.40^{\mathrm{c}}$ & 0.01 & 0.02 & 3.79 & $3.71^{\mathrm{ab}}$ & 0.04 & 0.19 & 3.59 & $3.76^{\mathrm{a}}$ & 0.02 & $<0.01$ & 0.02 & $<0.01$ \\
\hline 14:0 & 11.9 & $11.9^{\mathrm{a}}$ & 0.11 & 0.76 & 11.5 & $11.4^{\mathrm{b}}$ & 0.01 & 0.05 & 11.3 & $11.6^{\mathrm{b}}$ & 0.06 & 0.06 & 11.7 & $11.9^{\mathrm{a}}$ & 0.01 & $<0.01$ & 0.06 & $<0.01$ \\
\hline $15: 0$ & 1.08 & $1.10^{\mathrm{a}}$ & 0.01 & 0.38 & 1.04 & $0.98^{\mathrm{c}}$ & 0.01 & $<0.01$ & 1.07 & $1.04^{\mathrm{b}}$ & 0.01 & 0.11 & 1.10 & $1.06^{\mathrm{ab}}$ & 0.01 & $<0.01$ & 0.01 & $<0.01$ \\
\hline $16: 0$ & 26.4 & $26.9^{\mathrm{b}}$ & 0.11 & 0.04 & 26.5 & $26.8^{\mathrm{b}}$ & 0.05 & $<0.01$ & 26.9 & $27.5^{\mathrm{a}}$ & 0.15 & 0.04 & 27.3 & $26.4^{\mathrm{b}}$ & 0.07 & $<0.01$ & 0.11 & $<0.01$ \\
\hline $16: 1$ cis & 1.00 & $1.06^{\mathrm{xy}}$ & 0.02 & 0.09 & 1.03 & $1.05^{\mathrm{xy}}$ & 0.01 & 0.13 & 1.09 & $1.11^{\mathrm{x}}$ & 0.02 & 0.57 & 1.06 & $1.04^{\mathrm{y}}$ & 0.01 & 0.22 & 0.02 & 0.07 \\
\hline $18: 0$ & 12.9 & $12.5^{\mathrm{bc}}$ & 0.21 & 0.35 & 13.6 & $13.4^{\mathrm{a}}$ & 0.04 & 0.02 & 11.9 & $11.9^{\mathrm{c}}$ & 0.21 & 0.96 & 12.7 & $12.9^{\mathrm{ab}}$ & 0.06 & 0.07 & 0.14 & $<0.01$ \\
\hline 18:1 cis-9 & 17.2 & 17.7 & 0.34 & 0.38 & 17.5 & 17.9 & 0.09 & 0.04 & 17.6 & 17.4 & 0.10 & 0.24 & 17.0 & 17.3 & 0.04 & $<0.01$ & 0.20 & 0.33 \\
\hline $\begin{array}{l}\Sigma 18: 1 \text { trans }-10 / \\
\text { trans-11 }\end{array}$ & 1.62 & $1.67^{\mathrm{b}}$ & 0.04 & 0.43 & 1.66 & $1.63^{\mathrm{b}}$ & 0.02 & 0.26 & 1.88 & $1.84^{\mathrm{a}}$ & 0.01 & 0.03 & 1.91 & $1.89^{\mathrm{a}}$ & 0.02 & 0.53 & 0.03 & $<0.01$ \\
\hline $18: 2 \mathrm{n}-6$ & 1.36 & 1.31 & 0.04 & 0.45 & 1.35 & 1.38 & 0.01 & 0.02 & 1.40 & 1.31 & 0.01 & $<0.01$ & 1.29 & 1.31 & 0.01 & 0.32 & 0.02 & 0.14 \\
\hline $18: 3 \mathrm{n}-6$ & 0.02 & 0.03 & 0.01 & 0.09 & 0.03 & 0.03 & 0.01 & 0.51 & 0.02 & 0.03 & 0.01 & 0.71 & 0.03 & 0.02 & 0.01 & 0.08 & 0.01 & 0.17 \\
\hline $18: 3 n-3$ & 0.98 & $0.95^{\mathrm{b}}$ & 0.02 & 0.39 & 0.93 & $1.10^{\mathrm{a}}$ & 0.01 & $<0.01$ & 1.11 & $1.07^{\mathrm{a}}$ & 0.01 & 0.07 & 0.90 & $0.93^{\mathrm{b}}$ & 0.01 & 0.04 & 0.01 & $<0.01$ \\
\hline 20:0 & 0.22 & $0.22^{\mathrm{bc}}$ & 0.01 & 0.75 & 0.23 & $0.23^{\mathrm{a}}$ & 0.01 & 0.54 & 0.24 & $0.22^{\mathrm{b}}$ & 0.01 & 0.01 & 0.22 & $0.21^{\mathrm{b}}$ & 0.01 & 0.38 & 0.01 & $<0.01$ \\
\hline $20: 3 \mathrm{n}-6$ & 0.04 & $0.04^{\mathrm{b}}$ & 0.01 & 0.74 & 0.05 & $0.05^{\mathrm{ab}}$ & 0.01 & 0.58 & 0.05 & $0.05^{\mathrm{ab}}$ & 0.01 & 0.05 & 0.05 & $0.05^{\mathrm{a}}$ & 0.01 & 0.41 & 0.01 & 0.05 \\
\hline $20: 3 n-3$ & 0.02 & $0.02^{\mathrm{b}}$ & 0.01 & 0.34 & 0.02 & $0.02^{\mathrm{ab}}$ & 0.01 & 0.83 & 0.02 & $0.02^{\mathrm{a}}$ & 0.01 & 0.76 & 0.02 & $0.02^{\mathrm{b}}$ & 0.01 & 0.17 & 0.01 & 0.03 \\
\hline $20: 4$ n- 6 & 0.07 & 0.07 & 0.01 & 0.18 & 0.08 & 0.07 & 0.01 & 0.29 & 0.08 & 0.07 & 0.01 & 0.03 & 0.07 & 0.07 & 0.01 & 0.25 & 0.01 & 0.24 \\
\hline $20: 5 n-3$ & 0.10 & 0.09 & 0.01 & 0.43 & 0.09 & 0.10 & 0.01 & 0.05 & 0.09 & 0.09 & 0.01 & 0.42 & 0.09 & 0.09 & 0.01 & 0.15 & 0.01 & 0.23 \\
\hline $22: 5 n-3$ & 0.09 & $0.09^{\mathrm{b}}$ & 0.01 & 0.73 & 0.09 & $0.10^{\mathrm{a}}$ & 0.01 & 0.10 & 0.09 & $0.10^{\mathrm{ab}}$ & 0.01 & 0.59 & 0.09 & $0.09^{\mathrm{ab}}$ & 0.01 & 0.32 & 0.01 & 0.05 \\
\hline SCFA $^{1}$ & 11.8 & 11.6 & 0.20 & 0.40 & 11.7 & 11.7 & 0.05 & 0.84 & 11.6 & 11.7 & 0.14 & 0.55 & 11.7 & 11.9 & 0.06 & 0.10 & 0.13 & 0.43 \\
\hline $\mathrm{MCFA}^{2}$ & 46.9 & $47.6^{\mathrm{a}}$ & 0.18 & 0.07 & 46.5 & $46.7^{\mathrm{b}}$ & 0.05 & 0.12 & 47.2 & $48.0^{\mathrm{a}}$ & 0.25 & 0.11 & 47.9 & $47.3^{\mathrm{ab}}$ & 0.10 & 0.02 & 0.15 & $<0.01$ \\
\hline $\mathrm{LCFA}^{3}$ & 41.4 & $41.0^{\mathrm{ab}}$ & 0.35 & 0.50 & 42.0 & $41.8^{\mathrm{a}}$ & 0.05 & 0.07 & 41.4 & $40.5^{\mathrm{b}}$ & 0.35 & 0.16 & 40.6 & $41.0^{\mathrm{ab}}$ & 0.04 & $<0.01$ & 0.24 & 0.03 \\
\hline $\mathrm{SFA}^{4}$ & 70.2 & 70.0 & 0.45 & 0.69 & 70.3 & 70.1 & 0.11 & 0.24 & 69.1 & 69.8 & 0.10 & $<0.01$ & 70.5 & 70.2 & 0.06 & 0.04 & 0.31 & 0.79 \\
\hline MUFA $^{5}$ & 25.1 & 25.5 & 0.32 & 0.45 & 25.2 & 25.4 & 0.10 & 0.39 & 25.9 & 25.4 & 0.14 & 0.06 & 25.0 & 25.3 & 0.03 & 0.02 & 0.38 & 0.89 \\
\hline $\mathrm{PUFA}^{6}$ & 4.6 & 4.5 & 0.13 & 0.62 & 4.5 & 4.6 & 0.03 & 0.22 & 5.0 & 4.8 & 0.04 & 0.02 & 4.5 & 4.5 & 0.038 & 0.32 & 0.09 & 0.13 \\
\hline$\Sigma \mathrm{CLA}^{7}$ & 0.60 & $0.64^{\mathrm{bc}}$ & 0.03 & 0.42 & 0.58 & $0.57^{\mathrm{c}}$ & 0.01 & 0.40 & 0.74 & $0.74^{\mathrm{a}}$ & 0.01 & 0.98 & 0.70 & $0.67^{\mathrm{b}}$ & 0.010 & 0.13 & 0.02 & $<0.01$ \\
\hline$\sum \mathrm{n}-3^{8}$ & 1.64 & $1.58^{\mathrm{b}}$ & 0.06 & 0.38 & 1.57 & $1.71^{\mathrm{a}}$ & 0.01 & $<0.01$ & 1.83 & $1.76^{\mathrm{a}}$ & 0.02 & 0.06 & 1.54 & $1.54^{\mathrm{b}}$ & 0.013 & 0.84 & 0.03 & $<0.01$ \\
\hline$\Sigma \mathrm{n}-6^{9}$ & 2.76 & 2.57 & 0.04 & 0.03 & 2.63 & 2.55 & 0.02 & 0.04 & 2.77 & 2.55 & 0.03 & $<0.01$ & 2.52 & 2.47 & 0.021 & 0.16 & 0.03 & 0.14 \\
\hline \\
\hline \\
\hline \multicolumn{19}{|c|}{$\begin{array}{l}{ }^{1} \text { Sheatment means in ExP within the same row } \\
\text { Shain fatty acids: from } 4: 0 \text { to } 10: 1 .\end{array}$} \\
\hline \multicolumn{19}{|c|}{${ }^{2}$ Medium-chain fatty acids: from $12: 0$ to $16: 1$ cis. } \\
\hline \multicolumn{19}{|c|}{${ }^{3}$ Long-chain fatty acids: from $17: 0$ to $22: 6 \mathrm{n}-6$. } \\
\hline \multirow{2}{*}{\multicolumn{19}{|c|}{$\begin{array}{l}{ }^{4} \text { From } 4: 0 \text { to } 10: 0+12: 0,13: 0 \text { iso }+13: 0 \text { anteiso }+14: 0 \text { iso }+14: 0+15: 0 \text { iso }+15: 0 \text { anteiso }+15: 0+16: 0 \text { iso }+16: 0+17: 0 \text { iso }+17: 0 \text { anteiso }+18: 0 \text { iso }+18: 0 \text { anteiso }+18: 0 \\
+19: 0+20: 0+22: 0 \text {. }\end{array}$}} \\
\hline & \multicolumn{13}{|c|}{${ }^{5} 10: 1+14: 1+16: 1$ cis $+16: 1$ trans $+17: 1$ trans $+18: 1$ cis $+18: 1$ trans $+20: 1$ cis $+20: 1$ trans } & & & & & \\
\hline \multicolumn{19}{|c|}{${ }^{6}$ From 18:2 trans nonmethylene interrupted diene to $18: 2$ cis- 9 , cis- $15+18: 3 \mathrm{n}-6+$ from $18: 3 \mathrm{n}-3$ to $20: 2$ cis $\mathrm{n}-6$ + from $20: 3 \mathrm{n}-6$ to $22: 6 \mathrm{n}-3$. } \\
\hline \multicolumn{19}{|c|}{${ }^{7} 18: 2$ cis- 9, trans $-11+18: 2$ trans- 8, cis- $10+18: 2$ trans -7, cis $-9+18: 2$ trans- 11, cis $-13+18: 2$ cis- 9, cis $-11+18: 2$ trans -9, trans -11.} \\
\hline \multicolumn{19}{|c|}{${ }^{8} 18: 2$ trans- 11, cis- $15+18: 2$ trans -9, csi- $12+18: 2$ cis -9, cis $-15+18: 3 \mathrm{n}-3+20: 3 \mathrm{n}-3+20: 5 \mathrm{n}-3+22: 5 \mathrm{n}-3+22: 6 \mathrm{n}-3}$. \\
\hline \multicolumn{19}{|c|}{$\begin{array}{l}{ }^{9} 18: 1 \text { trans }-12+18: 1 \text { cis- } 12+18: 2 \text { trans }-9, \text { trans }-12+18: 2 \text { cis- } 9 \text {, trans- } 12+18: 2 \text { cis methylene interrupted diene }+18.2 \text { trans- } 8 \text {, cis- } 13+18: 2 \mathrm{n}-6+18: 3 \mathrm{n}-6+20: 2 \text { cis } \mathrm{n}-6+20: 3 \mathrm{n}-6 \\
+20: 4 \mathrm{n}-6 \text {. }\end{array}$} \\
\hline
\end{tabular}


Table 6. Gross chemical composition, volatile carboxylic acids, and biochemical indicators of cheeses aged for 8 mo and produced from the milk of cows during the control period $(\mathrm{CoP})$ and when fed the different legumes in the experimental period (ExP)

\begin{tabular}{|c|c|c|c|c|c|c|c|c|c|c|c|c|c|c|c|c|c|c|}
\hline \multirow[b]{2}{*}{ Item } & \multicolumn{4}{|c|}{ Alfalfa } & \multicolumn{4}{|c|}{ Sainfoin } & \multicolumn{4}{|c|}{ Birdsfoot trefoil Bull } & \multicolumn{4}{|c|}{ Birdsfoot trefoil Polom } & \multicolumn{2}{|c|}{ Treatment effect } \\
\hline & $\begin{array}{l}\mathrm{CoP} \\
\mathrm{n}=3\end{array}$ & $\begin{array}{l}\mathrm{ExP} \\
\mathrm{n}=3\end{array}$ & SEM & $P$-value & $\begin{array}{c}\mathrm{CoP} \\
\mathrm{n}=3\end{array}$ & $\begin{array}{c}\mathrm{ExP} \\
\mathrm{n}=3\end{array}$ & SEM & $P$-value & $\begin{array}{l}\mathrm{CoP} \\
\mathrm{n}=3\end{array}$ & $\begin{array}{c}\mathrm{ExP} \\
\mathrm{n}=3\end{array}$ & SEM & $P$-value & $\begin{array}{c}\mathrm{CoP} \\
\mathrm{n}=3\end{array}$ & $\begin{array}{c}\mathrm{ExP} \\
\mathrm{n}=3\end{array}$ & SEM & $P$-value & SEM & $P$-value \\
\hline \multicolumn{19}{|l|}{$\begin{array}{l}\text { Gross chemical } \\
\text { composition }(\%)\end{array}$} \\
\hline Moisture & 30.5 & 30.9 & 0.21 & 0.18 & 30.5 & 30.9 & 0.22 & 0.28 & 31.0 & 31.1 & 1.86 & 0.64 & 30.4 & 31.2 & 0.35 & 0.20 & 0.27 & 0.85 \\
\hline $\begin{array}{l}\text { Moisture on a } \\
\text { fat-free basis }\end{array}$ & 49.0 & 49.0 & 0.22 & 0.90 & 49.0 & 49.6 & 0.29 & 0.18 & 49.5 & 49.5 & 3.18 & 0.99 & 48.8 & 49.4 & 0.34 & 0.28 & 0.32 & 0.60 \\
\hline Fat in DM & 54.2 & $53.3^{\mathrm{b}}$ & 0.32 & 0.10 & 54.2 & $54.6^{\mathrm{a}}$ & 0.27 & 0.33 & 54.2 & $53.9^{\mathrm{ab}}$ & 4.04 & 0.65 & 54.1 & $53.6^{\mathrm{b}}$ & 0.36 & 0.40 & 0.15 & $<0.01$ \\
\hline Sodium chloride & 1.30 & 1.27 & 0.03 & 0.57 & 1.25 & 1.31 & 0.04 & 0.36 & 1.30 & 1.3 & 0.45 & 0.78 & 1.33 & 1.40 & 0.07 & 0.50 & 0.06 & 0.47 \\
\hline \multicolumn{19}{|l|}{$\begin{array}{l}\text { Volatile carboxylic } \\
\text { acids }(\mathrm{mmol} / \mathrm{kg})\end{array}$} \\
\hline Methanoic acid & 0.31 & 0.60 & 0.08 & 0.06 & 0.38 & 0.47 & 0.12 & 0.62 & 0.31 & 0.54 & 0.07 & 0.09 & 0.31 & 0.51 & 0.11 & 0.27 & 0.06 & 0.56 \\
\hline Acetic acid & 6.0 & 7.7 & 2.10 & 0.61 & 4.7 & 4.5 & 1.16 & 0.90 & 5.5 & 5.4 & 1.62 & 0.96 & 6.4 & 5.3 & 2.17 & 0.74 & 1.37 & 0.44 \\
\hline Propionic acid & 5.6 & 7.6 & 4.16 & 0.75 & 1.3 & 1.4 & 0.77 & 0.93 & 0.3 & 1.3 & 0.67 & 0.36 & 0.6 & 1.3 & 0.49 & 0.37 & 2.80 & 0.35 \\
\hline Butyric acid & 0.57 & $0.49^{\mathrm{b}}$ & 0.09 & 0.55 & 0.57 & $0.87^{\mathrm{ab}}$ & 0.08 & 0.05 & 0.62 & $0.85^{\mathrm{ab}}$ & 0.12 & 0.25 & 0.57 & $0.91^{\mathrm{a}}$ & 0.10 & 0.07 & 0.10 & 0.05 \\
\hline $\begin{array}{l}\text { Butyric acid from } \\
\text { fermentation }^{1}\end{array}$ & 0.18 & $0.48^{\mathrm{ab}}$ & 0.06 & 0.02 & 0.31 & $0.49^{\mathrm{ab}}$ & 0.04 & 0.03 & 0.24 & $0.30^{\mathrm{b}}$ & 0.03 & 0.28 & 0.24 & $0.51^{\mathrm{a}}$ & 0.02 & 0.02 & 0.05 & 0.04 \\
\hline Caproic acid & 0.13 & $0.01^{\mathrm{b}}$ & 0.05 & 0.13 & 0.09 & $0.13^{\mathrm{ab}}$ & 0.02 & 0.30 & 0.13 & $0.18^{\mathrm{a}}$ & 0.05 & 0.43 & 0.11 & $0.13^{\mathrm{ab}}$ & 0.03 & 0.58 & 0.03 & 0.02 \\
\hline Total & 12.7 & 16.4 & 6.33 & 0.70 & 7.0 & 7.4 & 1.88 & 0.89 & 6.9 & 8.3 & 1.85 & 0.62 & 8.0 & 8.3 & 2.34 & 0.93 & 4.13 & 0.42 \\
\hline \multicolumn{19}{|l|}{$\begin{array}{l}\text { Biochemical } \\
\text { indicators } \\
\text { (mmol/kg) }\end{array}$} \\
\hline Total lactic acid & 128.5 & 123.8 & 5.06 & 0.55 & 134.3 & 124.0 & 2.03 & 0.02 & 137.0 & 124.0 & 3.21 & 0.05 & 132.21 & 121.7 & 2.94 & 0.07 & 3.9 & 0.97 \\
\hline Free AA & 276.4 & 261.9 & 7.56 & 0.25 & 274.5 & 284.9 & 24.73 & 0.78 & 266.3 & 277.1 & 14.52 & 0.63 & 296.52 & 289.5 & 30.91 & 0.88 & 29.4 & 0.91 \\
\hline
\end{tabular}

${ }^{\mathrm{a}, \mathrm{b}}$ Treatment means in the ExP within the same row carrying no common superscript differ significantly at $P<0.05$.

${ }^{\mathrm{x}, \mathrm{y}}$ Treatment means in the $\mathrm{ExP}$ within the same row carrying no common superscript tend to differ significantly at $P<0.10$.

${ }^{1} 4: 0$ level from fermentation calculated with the following formula: total 4:0 $-(3 \times$ total 6:0). 
Table 7. Trimmed means ( $\pm \mathrm{SE}$ of trimmed means) of the grading made in sensory evaluation of the cheeses aged for 8 mo and produced from the milk of cows during the control period $(\mathrm{CoP})$ and when fed the legumes in the experimental period $(\mathrm{ExP})^{1}$

\begin{tabular}{|c|c|c|c|c|c|c|}
\hline \multirow[b]{2}{*}{ Item } & \multirow{2}{*}{$\frac{\mathrm{CoP}^{2}}{\text { Alfalfa }}$} & \multicolumn{4}{|c|}{ ExP } & \multirow[b]{2}{*}{$P$ value } \\
\hline & & Alfalfa & Sainfoin & $\begin{array}{l}\text { Birdsfoot } \\
\text { trefoil Bull }\end{array}$ & $\begin{array}{l}\text { Birdsfoot } \\
\text { trefoil Polom }\end{array}$ & \\
\hline \multicolumn{7}{|l|}{$\overline{\text { Structure }}$} \\
\hline Hardness & $6.33 \pm 0.418^{\mathrm{bc}}$ & $5.92 \pm 0.414^{\mathrm{c}}$ & $6.65 \pm 0.403^{\mathrm{ab}}$ & $6.88 \pm 0.431^{\mathrm{a}}$ & $6.68 \pm 0.439^{\mathrm{a}}$ & 0.02 \\
\hline Rind thickness & $2.70 \pm 0.463^{\mathrm{b}}$ & $3.33 \pm 0.454^{\mathrm{a}}$ & $2.81 \pm 0.322^{\mathrm{b}}$ & $3.44 \pm 0.415^{\mathrm{a}}$ & $2.79 \pm 0.375^{\mathrm{b}}$ & 0.03 \\
\hline Adhesiveness & $3.51 \pm 0.366^{\mathrm{xy}}$ & $3.73 \pm 0.367^{\mathrm{x}}$ & $3.02 \pm 0.355^{\mathrm{z}}$ & $3.09 \pm 0.354^{\mathrm{yz}}$ & $3.24 \pm 0.388^{\mathrm{yz}}$ & 0.08 \\
\hline \multicolumn{7}{|l|}{ Flavor } \\
\hline
\end{tabular}

no effect on milk yield and milk gross composition. A dietary CT level of up to $3 \%(3,0.9$, and $0.5 \%$ with $\mathrm{SF}, \mathrm{BB}$, and $\mathrm{BP}$, respectively), presented in the form of likely palatable pellets from dried material, had no adverse effect on feed intake and yield of milk, milk fat, and milk protein. A high milk protein content, especially in casein, is important for rennet coagulation and curd firmness in cheese manufacturing (discussed by Kälber et al. 2013). Greater casein content, and consequently milk protein content, was observed when feeding $\mathrm{BB}$ pellets after $\mathrm{AF}$ pellets, but this was not related to the intake of $\mathrm{CT}$ because dietary contents of these milk constituents were already greater in this group during the CoP.

The only clear effect of the CT on milk constituents, apart from fatty acid profile, was on milk urea level. This trait is a good indicator of excessive ruminal protein degradation, where the nonutilized ammonia is absorbed, metabolized to urea by the liver, and found in blood, urea, and milk. In the present study, feeding SF pellets with the highest CT content substantially decreased milk urea level because likely some dietary protein was bound and thus prevented from ruminal degradation. This was described earlier with feeding sainfoin in dairy cows and sheep (Scharenberg et al., 2007; Arrigo and Dohme, 2009; Grosse Brinkhaus et al., 2014). However, it seems that the CT level of the diets supplemented with the 2 birdsfoot trefoil cultivars was too low to reduce milk urea level.

\section{Effects on the Fatty Acid Profile of Milk and Cheese Lipids}

As expected, the fatty acid profile of the milk from individual cows was similar to that of the cheese. However, significant treatment effects on the fatty acid profile were less evident in the milk than in the cheese.
This is probably caused by the greater variability in the fatty acid profile of the milk from the 6 individual cows per treatment compared with the fatty acid profile of the cheese produced from a mix of those individual milks. For instance, after feeding SF pellets the 18:3n-3 level was increased by $17 \%$ both in the milk and in the cheese but it was only statistically significant in the cheese, for which the standard error of the mean is 12 times lower than in the milk. In the present experiment, using AF pellets both in the $\mathrm{CoP}$ and the ExP was chosen to distinguish between the effects of $\mathrm{CT}$ and of lactation stage. Therefore, when results were different in the $\mathrm{AF}$ group between the $\mathrm{CoP}$ and the ExP, one can attribute these differences primarily to the lactation stage.

Some effects of CT were noted on the fatty acid profile of the milk and the cheese in the present study, and SF was the legume which had the greatest effect of all $\mathrm{CT}$ legumes. It is particularly noteworthy that after feeding SF pellets the 18:3n-3 proportions of the milk and cheese lipids was elevated by $17 \%$ (significant in the cheese, tendency in the milk). This was associated with an increase in proportions of 2 of its elongation products, 20:5n-3 and 22:5n-3, in the cheese. Therefore, with SF the intention to decrease biohydrogenation rate of dietary PUFA was achieved. The 2 birdsfoot trefoil cultivars did not have this property, although they resulted in a higher intake of 18:3n-3 than before with AF, similar to SF. Apart from increasing n-3 fatty acid proportion, a favorable change in the fatty acid profile would also consist of elevating the levels of the 2 biohydrogenation intermediates $18: 1$ trans-11 and 18:2 cis-9,trans-11 (the most important CLA isomer). Vasta et al. (2010) described an increase in the proportion of these 2 intermediates in the rumen of sheep supplemented with quebracho $\mathrm{CT}$ (6.4\% CT in diet) in addition to an increase in the relative abundance of 
Butyrivibrio fibrosolvens and a decrease in the relative abundance of Butyrivibrio proteoclasticum. By contrast, in the present experiment, switching from AF to SF in the ExP resulted in a decrease in 18:1 trans-11 in the milk. In addition, feeding SF lead to a greater 18:1 cis-9 proportion and a lower proportion of 18:0 (the terminal product of biohydrogenation) in the cheese. Based on these results in the milk and the cheese and those obtained by Vasta et al. (2010) in the rumen, we can assume that biohydrogenation of dietary PUFA in the rumen was actually reduced by the sainfoin $\mathrm{CT}$. The 2 birdsfoots trefoil cultivars had only a minor effect on the fatty acid profile, but in some cases had contrasting effects on certain fatty acids. For instance, the total SFA proportion increased after feeding BB pellets at the expense of MUFA and PUFA, whereas the SFA level decreased and, concomitantly, the MUFA level increased after feeding BP pellets. In addition, compared with BB, BP was able to increase significantly the proportion of 18:2 cis-9,trans-11.

Most studies focusing on the effect of dietary CT on milk fatty acid profile were carried out with ewes. In the few studies with dairy cows, CT seem to have typically only minor effects on the fatty acid profile of the milk (Dschaak et al., 2011; Aprianita et al., 2014). However, despite the relatively low proportion of ExtruLin $(5 \%$ of the total ingredient on a DM basis) as the primary source of $18: 3 n-3$ in the diets, an increase of $18: 3 n-3$ proportion in the milk of cows fed sainfoin CT was observed in the present study. Similar effects were also reported by Turner et al. (2005), who compared birdsfoot trefoil and birdsfoot trefoil with polyethylene glycol (1.37 vs $1.07 \%$ of $18: 3 \mathrm{n}-3$, respectively), and Dschaak et al. (2011), who added quebracho tannins extract to forage ( 0.39 vs $0.35 \%$ of $18: 3 \mathrm{n}-3$ with or without tannins extract, respectively). The present results, obtained with different legumes containing CT, suggest that the CT content is an important factor. However, despite a similar CT intake, the different response of feeding the 2 birdsfoots trefoil cultivars on milk and cheese fatty acids indicates that the source of the $\mathrm{CT}$ and their chemical structure might be of relevance. The CT are polymers constituted of different types of monomers and flavan-3-ols (catechin, epicatechin, gallocatechin, epigallocatechin) and of different size (e.g., degree of polymerization). Even in the same species, Azuhnwi et al. (2013) found that CT have different chemical structures. These aforementioned structural differences can modify the reactivity of the CT toward protein, as suggested by Sarni-Manchado et al. (1999). Barry and McNabb (1999) showed that the most polymerized CT bind more tightly to protein than the least polymerized CT. In addition, flavan-3-ols gallate, sesquiterpene, or saponins could play a similar role as CT (Wallace et al., 1994; Molan et al., 2003; Ahmed et al., 2014), but no more detailed analysis of the total polyphenols and other components were made with the present legume material.

\section{Effect on Sensory Quality of Milk and Cheese, and on Cheese Composition}

The current study demonstrated that effects of the CT legumes on the sensory properties of milk and cheese were limited. One exception was that the odor of the milk from cows fed BB was different to that obtained from cows fed AF in the ExP. Unfortunately, with this kind of test it is not possible to say in which way (better or worse) it differed. Compared with the other groups this milk had more protein, but milk protein was already higher in the $\mathrm{CoP}$ for this BB group. Thus, the protein content cannot explain the difference in odor, which was not recovered in the cheese, except maybe through a slightly more pronounced sour taste of the cheese from the BB group compared with cheese from other origins. Carpino et al. (2004) showed that inclusion of $15 \%$ of fresh grass to a diet composed of corn silage, hay, and concentrate was sufficient to change color, firmness, and flavor of the cheese, but this was probably associated with changes in milk gross composition. This was not the case in the present study when including $18 \%$ of CT-containing legumes; therefore, no content effects on proteolysis and lactic acid content were to be expected. In addition, the changes occurring in fatty acid profile of milk and cheese were small enough to not affect the sensory assessment of the cheese by the panel.

However, some structural changes were noted in the cheeses by the panelists when cheeses from differently fed cows were compared, including hardness, rind thickness, and adhesiveness. Firmness of cheese depends on the $16: 0$ and $18: 1$ content in the milk fat, with $16: 0$ making the cheese harder and 18:1 making it softer (Stoll et al., 2003; Hurtaud and Peyraud, 2007). An increase in moisture content of the cheese has been correlated with an increase in cheese adhesiveness (Childs et al., 2007). However, neither the level of 16:0 and 18:1 nor the moisture content were responsible for the observed structural changes, as these traits were similar among the 4 experimental treatments.

\section{CONCLUSIONS}

The design of this study, consisting of keeping the same diet $(\mathrm{AF})$ in the $\mathrm{CoP}$ and the ExP, was chosen to be able to quantify and distinguish the effects of the lactation stage and the experimental diets. Thus, in the AF group small but significant differences between 
$\mathrm{CoP}$ and ExP were primarily attributed to lactation stage. Nevertheless, the present study showed that with a legume rich in $\mathrm{CT}$, such as sainfoin, resulting in a diet containing $3 \%$ total $\mathrm{CT}$, the 18:3n-3 level of dairy products can be elevated; this confirmed that CT can increase proportions of some beneficial PUFA both in milk and Gruyère cheese. However, the effects of the 2 birdsfoot trefoil cultivars were not comparable to those of sainfoin, supporting the hypothesis that effects depend on the plant species, likely due to the low CT contents in the 2 birdsfoot trefoil cultivars. Due to the large differences in CT levels to sainfoin, it was not possible to distinguish between effect of CT content and $\mathrm{CT}$ properties. The present study also demonstrated that inclusion of $18 \%$ of sainfoin produced cheese with only few distinguishable sensory changes, which were more related to structure than flavor. This largely disproves that odor and flavor were negatively affected by CT for the dietary situations tested. Another important finding promoting the use of sainfoin in dairy cow diets was that replacing a high-quality legume, such as alfalfa, with sainfoin was possible without adverse side effects on intake and milk yield.

\section{ACKNOWLEDGMENTS}

This study was supported by the European Marie Curie Initial Training Network ('LegumePlus'; PITNGA-2011-289377). The authors gratefully acknowledge and thank the skilled technical assistance of the experimental farm, analytic and sensory analysis departments of Agroscope in Posieux and Liebefeld, and Werner Luginbühl of ChemStat (Chemometrik und Statistik, Berne, Switzerland) for the assistance in statistical analysis of the sensory evaluation.

\section{REFERENCES}

Aerts, R. J., T. N. Barry, and W. C. McNabb. 1999. Polyphenols and agriculture: Beneficial effects of proanthocyanidins in forages. Agric. Ecosyst. Environ. 75:1-12. http://dx.doi.org/10.1016/S01678809(99)00062-6.

Agroscope. 2014, Fütterungsempfehlungen und Nährwerttabellen für Wiederkäuer (Feeding recommendations and nutrient tables for ruminants). Accessed Mar. 20, 2015. http://www.agroscope. admin.ch/futtermitteldatenbank/04834/index.html?lang=de.

Ahmed, S. T., J. W. Lee, H. S. Mun, and C. J. Yang. 2014. Effects of supplementation with green tea by-products on growth performance, meat quality, blood metabolites and immune cell proliferation in goats. J. Anim. Physiol. Anim. Nutr. http://dx.doi. org/10.1111/jpn.12279.

Ampuero Kragten, S., M. Collomb, S. Dubois, and P. Stoll. 2014. Composition des acides gras dans l'alimentation animale-Méthodes d'analyse. Rech. Agron. Suisse. 5:330-337.

AOAC International. 1995. Official Methods of Analysis. 16th ed. AOAC International, Arlington, VA.
AOAC International. 2000. Official Methods of Analysis. 17th ed. AOAC International, Gaithersburg, MD.

Aprianita, A., O. N. Donkor, P. J. Moate, S. R. O. Williams, M. J. Auldist, J. S. Greenwood, M. C. Hannah, W. J. Wales, and T. Vasiljevic. 2014. Effects of dietary cottonseed oil and tannin supplements on protein and fatty acid composition of bovine milk. J. Dairy Res. 81:183-192. http://dx.doi.org/10.1017/ S0022029914000065.

Arrigo, Y., and F. Dohme. 2009. Sainfoin versus alfalfa as supplements for grazing cows. Agrar Forsch. Schweiz 41:283-288.

Azuhnwi, B. N., B. Boller, F. Dohme-Meier, H. D. Hess, M. Kreuzer, E. Stringano, and I. Mueller-Harvey. 2013. Exploring variation in proanthocyanidin composition and content of sainfoin (Onobrychis viciifolia). J. Sci. Food Agric. 93:2102-2109. http://dx.doi. org/10.1002/jsfa.6119.

Barry, T. N., and W. C. McNabb. 1999. The implications of condensed tannins on the nutritive value of temperate forages fed to ruminants. Br. J. Nutr. 81:263-272.

Brunner, E., S. Domhof, and F. Langer. 2002. Nonparametric Analysis of Longitudinal Data in Factorial Experiments. Wiley, New York, NY.

Buccioni, A., M. Pauselli, C. Viti, S. Minieri, G. Pallara, V. Roscini, S. Rapaccini, M. T. Marinucci, P. Lupi, G. Conte, and M. Mele. 2015. Milk fatty acid composition, rumen microbial population, and animal performances in response to diets rich in linoleic acid supplemented with chestnut or quebracho tannins in dairy ewes. J. Dairy Sci. 98:1145-1156. http://dx.doi.org/10.3168/jds.2014-8651.

Bütikofer, U., and Y. Ardö. 1999. Quantitative determination of free amino acids in cheese. Pages 24-32 in Chemical Methods for Evaluating Proteolysis in Cheese Maturation. Bull. No. 337. International Dairy Federation, Brussels, Belgium.

Carpino, S., J. Horne, C. Melilli, G. Licitra, D. M. Barbano, and P. J. Van Soest. 2004. Contribution of native pasture to the sensory properties of Ragusano cheese. J. Dairy Sci. 87:308-315. http:// dx.doi.org/10.3168/jds.S0022-0302(04)73169-0.

Casey, M. G., J. O. Bosset, U. Bütikofer, and M. T. Fröhlich-Wyder. 2004. Effect of $\alpha$-keto acids on the development of flavour in Swiss Gruyere-type cheese. Lebenson. Wiss. Technol. 37:269-273.

Cavadini, C., A. M. Siega-Riz, and B. M. Popkin. 2000. US adolescent food intake trends from 1965 to 1996. Arch. Dis. Child. 83:18-24.

Childs, J. L., C. R. Daubert, L. Stefanski, and E. A. Foegeding. 2007. Factors regulating cheese shreddability. J. Dairy Sci. 90:2163-2174. http://dx.doi.org/10.3168/jds.2006-618.

Deckelbaum, R. J., and C. Torrejon. 2012. The omega-3 fatty acid nutritional landscape: Health benefits and sources. J. Nutr. 142:587S-591S. http://dx.doi.org/10.3945/jn.111.148080.

Dohme-Meier, F., and G. Bee. 2012. Feeding unprotected CLA methyl esters compared to sunflower seeds increased milk CLA level but inhibited milk fat synthesis in cows. Asian-australas. J. Anim. Sci. 25:75-85. http://dx.doi.org/10.5713/ajas.2011.11146.

Doreau, M., and A. Ferlay. 1993. Digestion and utilisation of fatty acids by ruminants. Anim. Feed Sci. Technol. 45:379-396. http:// dx.doi.org/10.1016/0377-8401(94)90039-6.

Dschaak, C. M., C. M. Williams, M. S. Holt, J. S. Eun, A. J. Young, and B. R. Min. 2011. Effects of supplementing condensed tannin extract on intake, digestion, ruminal fermentation, and milk production of lactating dairy cows. J. Dairy Sci. 94:2508-2519. http://dx.doi.org/10.3168/jds.2010-3818.

Goy, D., P. Piccinali, D. Wechsler, and E. Jakob. 2011. Caractérisation du gruyère AOC (appellation d'origine contrôlée). ALP Science No 536. Station de recherche Agroscope Liebefeld-Posieux, Bern, Switzerland. First accessed on Jan. 22, 2014. http://www. agroscope.admin.ch/publikationen/07703/07707/07710/index. html?lang=deune.

Grosse Brinkhaus, A., G. Bee, M. Kreuzer, and F. Dohme-Meier. 2014. Effect of condensed tannins from legumes on nitrogen balance and ruminal fermentation of dairy cows. Page 129 in 65th Annual Meeting of the European Federation of Animal Science, Copenhagen, Denmark. Wageningen Academic Publ., Wageningen, the Netherlands. 
Haug, A., A. T. Hostmark, and O. M. Harstad. 2007. Bovine milk in human nutrition: A review. Lipids Health Dis. 6:1-16.

Hurtaud, C., and J. L. Peyraud. 2007. Effects of feeding camelina (seeds or meal) on milk fatty acid composition and butter spreadability. J. Dairy Sci. 90:5134-5145. http://dx.doi.org/10.3168/ jds.2007-0031.

International Organization for Standardization (ISO). 2001. ISO 14156|IDF 172: Milk and Milk Products-Extraction Methods for Lipids and Liposoluble Compounds. ISO, Geneva, Switzerland.

International Organization for Standardization (ISO). 2002. ISO 15884|IDF 182: Milk Fat-Preparation of Fatty Acid Methyl Esters. ISO, Geneva, Switzerland.

International Organization for Standardization (ISO). 2003. ISO 13299: Sensory Analysis-Methodology-General Guidance for Establishing a Sensory Profile. ISO, Geneva, Switzerland.

International Organization for Standardization (ISO). 2004. ISO 14637|IDF 195: Milk-Determination of Urea Content-Enzymatic Method Using Difference in $\mathrm{pH}$ (Reference Method). ISO, Geneva, Switzerland.

International Organization for Standardization (ISO). 2006. ISO 5943|IDF 88: Cheese and processed cheese products-Determination of chloride content-Potentiometric titration method. ISO, Geneva, Switzerland.

International Organization for Standardization (ISO). 2008. ISO 707 Milk and milk products - Guidance on sampling. ISO, Geneva, Switzerland.

Jones, G. A., T. A. McAllister, A. D. Muir, and K. J. Cheng. 1994. Effects of sainfoin (Onobrychis viciifolia Scop.) condensed tannins on growth and proteolysis by four strains of ruminal bacteria. Appl. Environ. Microbiol. 60:1374-1378.

Kälber, T., M. Kreuzer, and F. Leiber. 2013. Effect of feeding buckwheat and chicory silages on fatty acid profile and cheese-making properties of milk from dairy cows. J. Dairy Res. 80:81-88. http:// dx.doi.org/10.1017/S0022029912000647.

Kepler, C. R., K. P. Hirons, J. J. McNeill, and S. B. Tove. 1966. Intermediates and products of the biohydrogenation of linoleic acid by Butyrivibrio fibrisolvens. J. Biol. Chem. 241:1350-1354.

Khiaosa-Ard, R., S. F. Bryner, M. R. L. Scheeder, H. R. Wettstein, F. Leiber, M. Kreuzer, and C. R. Soliva. 2009. Evidence for the inhibition of the terminal step of ruminal alpha-linolenic acid biohydrogenation by condensed tannins. J. Dairy Sci. 92:177-188. http://dx.doi.org/10.3168/jds.2008-1117.

Kristensen, D., R. V. Hedegaard, J. H. Nielsen, and L. H. Skibsted 2004. Oxidative stability of buttermilk as influenced by the fatty acid composition of cows' milk manipulated by diet. J. Dairy Res. 71:46-50. http://dx.doi.org/10.1017/S002202990300654X

Martin, B., I. Verdier-Metz, S. Buchin, C. Hurtaud, and J.-B. Coulon. 2005. How do the nature of forages and pasture diversity influence the sensory quality of dairy livestock products? Anim. Sci. 81:205-212.

Mensink, R. P., P. L. Zock, A. D. Kester, and M. B. Katan. 2003. Effects of dietary fatty acids and carbohydrates on the ratio of serum total to HDL cholesterol and on serum lipids and apolipoproteins: a meta-analysis of 60 controlled trials. Am. J. Clin. Nutr. $77: 1146-1155$.

Molan, A. L., L. P. Meagher, P. A. Spencer, and S. Sivakumaran. 2003. Effect of flavan-3-ols on in vitro egg hatching, larval development and viability of infective larvae of Trichostrongylus colubriformis. Int. J. Parasitol. 33:1691-1698.

Noguchi, K., Y. R. Gel, E. Brunner, and F. Konietschke. 2012. nparLD: An R software package for the nonparametric analysis of longitudinal data in factorial experiments. J. Stat. Softw. 50:1-23. http://dx.doi.org/10.18637/jss.v050.i12.
O’Mahony, M. 1992. Understanding discrimination tests: A userfriendly treatment of response bias, rating and ranking R-index tests and their relationship to signal detection. J. Sens. Stud. $7: 1-47$.

Salminen, J. P., and M. Karonen. 2011. Chemical ecology of tannins and other phenolics: We need a change in approach. Funct. Ecol. 25:325-338.

Sarni-Manchado, P., V. Cheynier, and M. Moutounet. 1999. Interactions of grape seed tannins with salivary proteins. J. Agric. Food Chem. 47:42-47.

Scharenberg, A., Y. Arrigo, A. Gutzwiller, U. Wyss, H. D. Hess, M. Kreuzer, and F. Dohme. 2007. Effect of feeding dehydrated and ensiled tanniferous sainfoin (Onobrychis viciifolia) on nitrogen and mineral digestion and metabolism of lambs. Arch. Anim. Nutr. 61:390-405.

Shingfield, K. J., Y. Chilliard, V. Toivonen, P. Kairenius, and D. I. Givens. 2008. Trans fatty acids and bioactive lipids in ruminant milk. Pages 3-65 in Bioactive Components of Milk. Advances in Experimental Medicine and Biology. Vol 606. Z. Böste, ed. Springer, New York, NY.

Stoll, W., H. Sollberger, M. Collomb, and W. Schaeren. 2003. Les graines de colza, de lin et de tournesol dans l'alimentation de la vache laitière. Rech. Agron. Suisse 10:354-359.

Terrill, T. H., A. M. Rowan, G. B. Douglas, and T. N. Barry. 1992. Determination of extractable and bound condensed tannin concentrations in forage plants, protein-concentrate meals and cereal-grains. J. Sci. Food Agric. 58:321-329.

Thanner, S., F. Dohme-Meier, S. Görs, C. C. Metges, R. M. Bruckmaier, and F. Schori. 2014. The energy expenditure of 2 Holstein cow strains in an organic grazing system. J. Dairy Sci. 97:2789-2799. http://dx.doi.org/10.3168/jds.2013-7394.

Timmons, J. S., W. P. Weiss, D. L. Palmquist, and W. J. Harper. 2001. Relationships among dietary roasted soybeans, milk components, and spontaneous oxidized flavor of milk. J. Dairy Sci. 84:24402449. http://dx.doi.org/10.3168/jds.S0022-0302(01)74694-2.

Turner, S. A., G. C. Waghorn, S. L. Woodward, and N. A. Thomson 2005. Condensed tannins in birdsfoot trefoil (Lotus corniculatus) affect the detailed composition of milk from dairy cows. Proc. N.Z Soc. Anim. Prod. 65:283-289.

Vasta, V., M. Mele, A. Serra, M. Scerra, G. Luciano, M. Lanza, and A. Priolo. 2009a. Metabolic fate of fatty acids involved in ruminal biohydrogenation in sheep fed concentrate or herbage with or without tannins. J. Anim. Sci. 87:2674-2684. http://dx.doi.org/10.2527/ jas.2008-1761.

Vasta, V., A. Priolo, M. Scerra, K. G. Hallett, J. D. Wood, and O. Doran. 2009b. Delta(9) desaturase protein expression and fatty acid composition of longissimus dorsi muscle in lambs fed green herbage or concentrate with or without added tannins. Meat Sci. 82:357-364. http://dx.doi.org/10.1016/j.meatsci.2009.02.007.

Vasta, V., D. R. Yanez-Ruiz, M. Mele, A. Serra, G. Luciano, M. Lanza, L. Biondi, and A. Priolo. 2010. Bacterial and protozoal communities and fatty acid profile in the rumen of sheep fed a diet containing added tannins. Appl. Environ. Microbiol. 76:2549-2555. http://dx.doi.org/10.1128/AEM.02583-09.

Wallace, R. J., L. Arthaud, and C. J. Newbold. 1994. Influence of Yucca shidigera extract on ruminal ammonia concentrations and ruminal microorganisms. Appl. Environ. Microbiol. 60:1762-1767.

Wallace, R. J., L. C. Chaudhary, N. McKain, N. R. McEwan, A. J. Richardson, P. E. Vercoe, N. D. Walker, and D. Paillard. 2006. Clostridium proteoclasticum: A ruminal bacterium that forms stearic acid from linoleic acid. FEMS Microbiol. Lett. 265:195-201.

Williams, C. M. 2000. Dietary fatty acids and human health. Ann. Zootech. 49:165-180. http://dx.doi.org/10.1051/animres:2000116. 